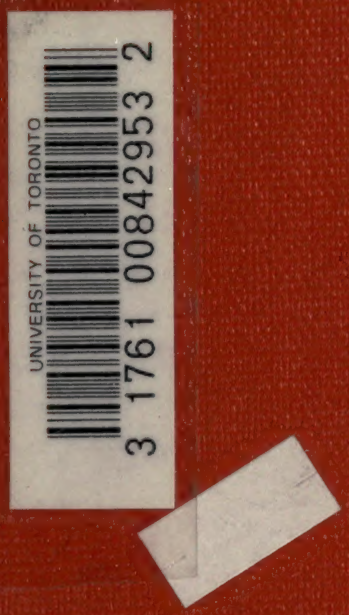


Digitized by the Internet Archive in 2008 with funding from Microsoft Corporation 

THE BEECH WOODS 



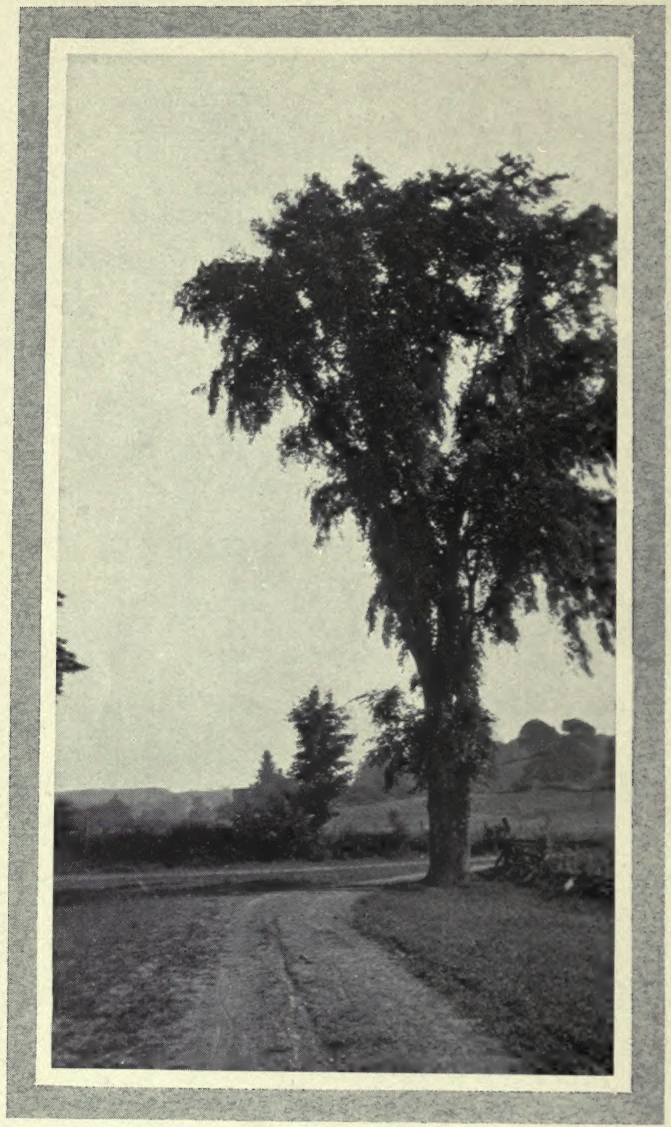

The Road to the Beech Woods. 


\section{The \\ BEECH WOODS}

How the Neighbour

Learned the Many

Secrets of a

CANADIAN WOODS

By

DUNCAN ARMBREST

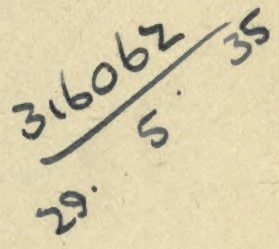

TORONTO

WILLIAM BRIGGS

1916 


$$
\begin{aligned}
& Q H \\
& 81 \\
& A 7
\end{aligned}
$$

COPrReGt OANADA, 1916,
DUNCAN ARMBREST 
Ja Ally Alluther 



\section{INTRODUCTION}

NE June day a flutter of wings was heard on the ground beside the barn. Here the Neighbour found a young swallow beating the impeding grass with ineffectual strokes. From its nest beneath the eaves it had gazed out upon a world of green fields flooded with Summer sunshine and, under the sudden impulse to follow its kind, spread its untried wings only to fall helpless to the ground. The Neighbour, under protests from its many friends, tossed it upward toward the security of the barn roof. Finding itself free from the tangled grass and strengthened by its efforts, it caught the wind and sped away across the fields, encouraged by rejoicing kindred wildly diving about it in a mad ecstacy of delight.

In presenting these observations and impressions as his first literary venture, the author feels not unlike the young swallow trying his wings for the first time, but hopes the reader not only 
finds pleasure in the perusal of these pages, but a new incentive to see more of the open fields and woods.

Acknowledgment is given to the editor of the Canadian Magazine for the kind permission to use an article previously contributed by the author and which is incorporated in the first chapter; also to Ethelwyn Wetherald for her valued assistance and the privilege of quoting from "The Last Robin."

\section{Sincerely,}

Duncan Armbrest.

Toronto. 


\section{CONTENTS}

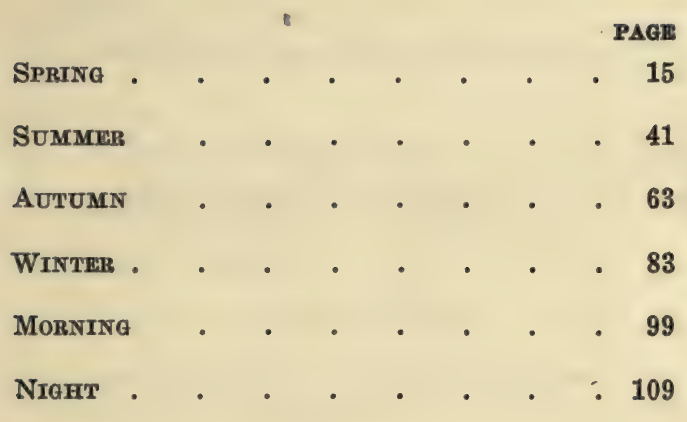





\section{LIST OF ILLUSTRATIONS}

PAGE

The Road to the Beech Woods. Frontispiece

A Clear Sheet of Water Ran Past the Elms 16

The Raccoon Descended from his Winter Home . . . . . . . 18

The Neighbour's Dog Came to the Woods 18

Nature has Painted the Beech with a Variety of Delicate Tints . . . 24

The Mirrored Pools of the Woods . . 32

The Giant Chestnut . . . . . 42

The Entrance to the Wood-Path . . 46

Down Among the Whip Trees the Wood Folk had Their Paths . : . 48

Down the Gray Aisles of the Beeches $\quad$. 52

The Vanguard of the Storm Pushed Slowly Across the Sun . . . . . 58

The Partridge Berry Grew About the old Pine Stump . . . . . . 58

An Opalescent Light Flooded the Cornfield . . . . . . . 64

The Road to the South of the Beech Woods 64 


\section{ILLUSTRATIONS}

PAGE

A Riot of Colour Went Rippling Across the Face of the Woods . . . . 68

The Creek Once More Resumed its Customary Way . . . . . . 74

Down in the Valley of the Beeches . $\quad 76$

The Season of Rest and Sleep had Come . 84

Winter's First White Blanket . . $\quad 86$

The Crows Knew Where There was an Abundance of Food . . . . 88

Each Stump was Crowned with White $\quad 92$

The Winter Path . . . . 92

The Morning Mists Came Creeping Down the Hollows . . . . . 102

The Morning Light . . . . . 104

The Magic Silence of the Evening Settled

Over Fields and Woods . . . 112

The Moonlight Came Filtering Through the Trees . . . . . . 116 
SPRING

.

. 



\section{SPRING}

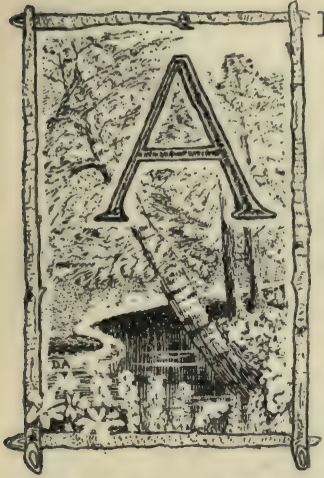

FTER many days of severe frost there came a night when there was a sound of musketry in the woods. Trees were cracking continuously and from the pond came a great boom, which went ripping up the creek, past the elms and into the heart of the Beech Woods, sending a thousand echoes out upon the still night. Winter was making her last stand.

Through the days that followed, a black curtain of haze hung low on the horizon to the north. The air was soft and caressing, full of rumours of the South, flowers and sunshine and the vast migrations of feathered folk that had already begun.

Over the ice in the creek a broad, clear sheet of water came sweeping out past the elms and flooded the pond. It 


\section{THE BEECH WOODS}

did not rest there, but journeyed on through the fields and meadows, under bridges and old rail fences down to the Chippewa.

Close on the heels of the great thaw the March wind came and swept the woods with vociferous thunderings. It sang and shouted and tossed the giant tops at will, threshing the supple limbs about in its boisterous play. It flew down the avenues in majestic strides, hurtling last year's leaves from place to place. Like a thousand charging steeds they raced through the woods, past the gray boles of the beeches, to rest for a moment in some hollow until the caprice of another eddying gust sent them charging back again. All day the wind roared through the woods until the dead limbs were shaken from the trees and the leaves of last autumn, swept from the exposed hillsides, piled in drifts behind the logs and the hollows levelled full.

At night the wind died down. The roar of battle ceased for a time. The raccoon descended from his winter home by the creek and hunted the pools for 


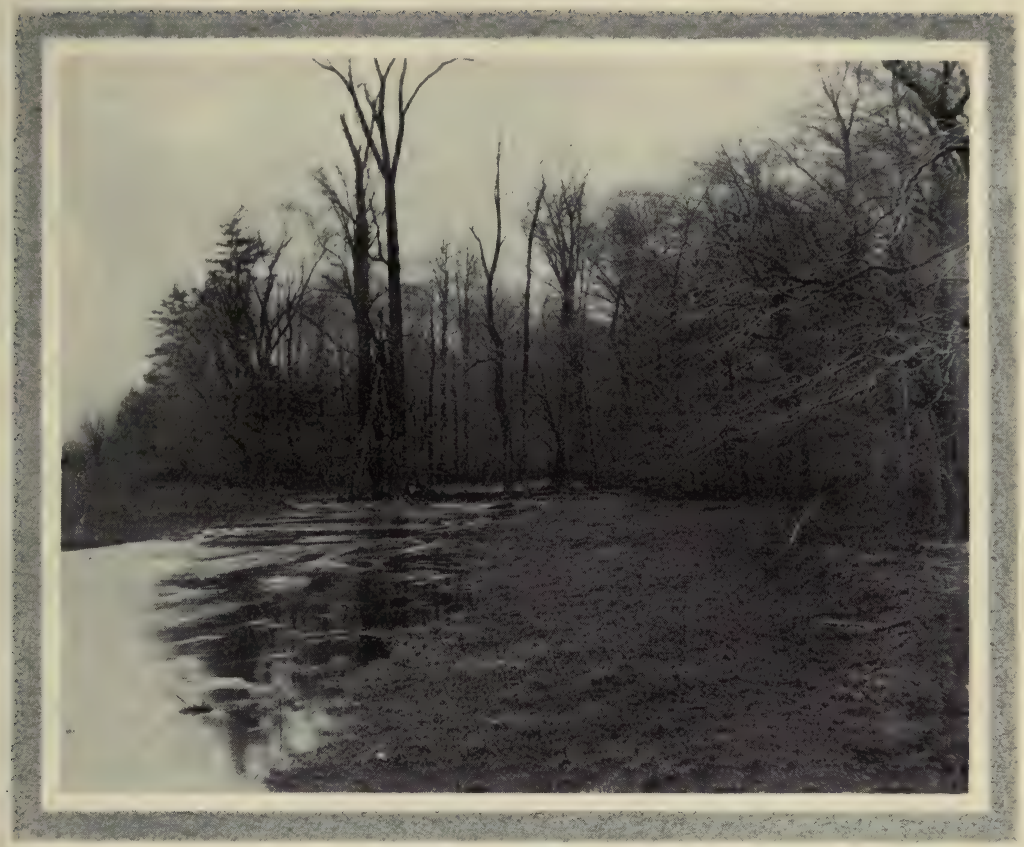

A Clear Sheet of Water Ran Past the Elms. 

food. From time to time he sent forth his trilling message of love upon the still night and started his nocturnal wanderings in search of a mate. In the grey of the dawn, well fed and far from his home tree, he climbed to some hollow limb to sleep through the day.

Steaming up from the drying earth the pungent odours of dead leaves and moss arose, filling the air with the very essence of Spring. This is the indomitable call of the out-of-doors. It is not the light of the morning, nor the lengthening of days, nor the call of the first robin which awakens the Spring unrest, but the magic breeze that floats in at the open window, laden with memories of a glorious green earth. This is the potent incense which awakens the ancestral vagabondage of man and drives him out to seek the healing of the sky and fields and woods.

Who has not climbed to some hill top where the great mellow winds of Spring blow down from heaven, or stood upon some river marge, or, passing by the forest's edge, caught the sweet woododour of the newly-born season and, 


\section{THE BEECH WOODS}

breathing deeply of the vivifying air, felt the wild impulse to run away? Away anywhere would do, just to be moving somewhere with mammoth strides and heart as light and carefree as a ten-year-old; away from the prosaic, everyday things of life, and go search for the land of Arcadia. This is the primal instinct following us down through the ages, from cave to tepee, from tepee to hut and from hut to apartment. It is the ancient germ of restlessness which rouses us, even as it did the nomad, eons and eons ago.

A voice from the pond awoke, and was joined by another and another. As the nights became warmer a perfect oratorio of praise ascended along the creek and far back to the dark pools of the woods. The clear musical voices of the toads, tremulous and sustained in their calls, drown all other voices of the night and continue even after the dawn. They are true harbingers of Summer warmth.

At this time the Beech Woods begin to take on new life. In the centre, 

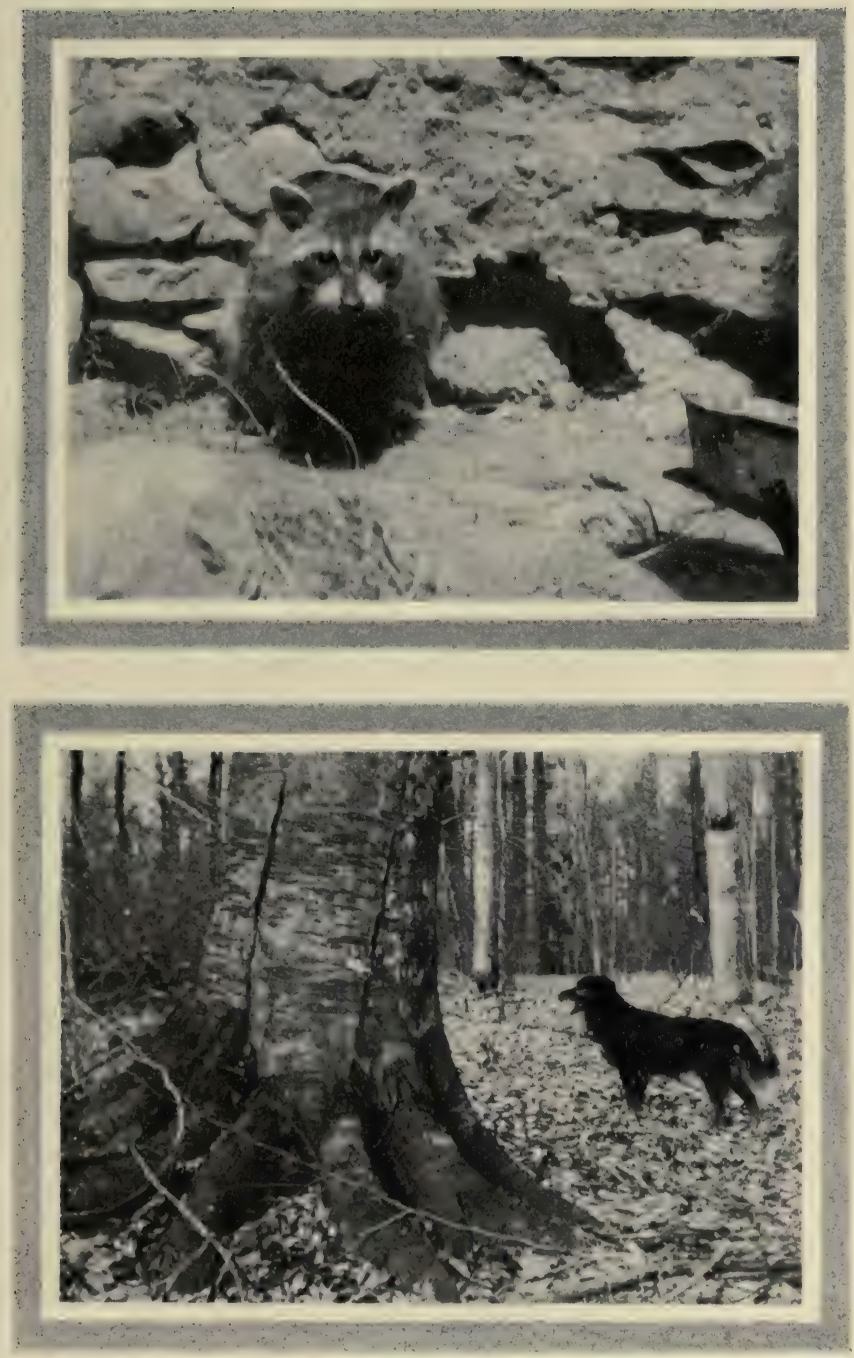

The Raceoon Descended from his Winter Home.

The Neighbour's Dog Came to the Wonds. 

where the old snake fence winds its way among the trees; the gray and black squirrels began to frisk about and renew acquaintance with their kind. They played tag among the upper branches and sped along the smooth limbs, leaping the open spaces between and sailing gracefully through the air with broad outstretched tails, alighting on the very finger-tip of a swaying branch. When they reached a roughbarked maple they changed their game to hide-and-seek and went circling round and round the trunk in reckless chase. Like children let loose from school, they frolicked in the sunshine and the newborn freedom of Spring. However, they seldom strayed far from their home trees. Besides the danger from the Neighbour's dog, who sometimes interrupted their foraging expeditions on the forest floor, they had a natural enemy who was a constant menace to their life and happiness. The reds often made life a trial and drove them home, where they remained to scold in harsh defiance. The gray squirrel, with his slow movements and 
his peaceful nature, is no match for the peppery red, who is a fierce fighter and always a bad neighbour to his gray and black kindred.

The winter birds seldom strayed from their pine thicket to the north, and only occasionally was the silence of the Beech Woods enlivened with the shrill cry of the jay or the merry voice of the chickadee. But now the drummer came to call the scattered army of the feathered tribes together. From the top of a hollowed stub there sounded on the morning air the long roll of the flicker, heralding the arrival of Spring and alternately making the woods resound with "Weecher, weecher," a note true to the woods. A robin carolled from the topmost branch of the old beech by the road and a song-sparrow, on his favourite stake in the fence below, answered with his one splendid tune. Of the robin's song there was no beginning and no end, no subtle prelude, no grand climax, but a continuous flow of pulsating melody. The sparrow below sang an old song, suggestive of the dawn in its first clear 


\section{SPRING}

notes, then growing in fervour and ending in a mad, ecstatic whirl. Oft repeated it was assuring, assuring to all renewing life that Spring had really come.

The bluebirds examined last year's home in the birch, making many temporary visits inside through the little door, all the while holding an animated conversation. One of the most interesting sights to be found at this season is to watch a pair of bluebirds choosing a home or refitting an old one, which they often do. The beautiful blue coat and red-brown breast is a most welcome bit of colour in the awakening Spring and their low, sweet music is a treat to hear when they are busy planning to set up house.

Every day added numbers to the army of choristers, each hour new voices were heard to swell the grand festival of song. The meadow-larks returned to the meadow at the east of the woods and gave an added touch of life to the creeping greenness of the fields. The family of the crows, who all through early Spring had been dis- 
turbers of the peaceful woods, now became silent and wary as they began the business of home-making. Echoes from the farmyard of the Neighbour reached the woods; echoes of the turmoil and strife of battle. The English sparrows - those rogues of the bird world-do not sing, but fight or dance their way to the heart of a mate with a dizzy reel or a stately cotillion, as the case requires.

Down by the creek the "pussy willow" catkins hung loaded with yellow pollen. Buds swelled in the warm sunshine, and the earliest flowering treethe June berry - showed its white stars at the border of the woods. Long before this the hepaticas had pushed their dainty flowers above the soil and run riot among the roots of the beeches. The yellow adder's-tongue, with its beautiful spotted leaves, grew abundantly along the eastern clearing and nodded in banks of yellow loveliness. The first hint of renewing life-that purplish haze of the far Spring woods -became more varied each day by yellowish-green touches of colour appear- 
ing where the buds of the earlier shrubs and trees were swelling into life. At this time the Neighbour often came with his dog to walk among the trees and share in the great new hope of the squirrels and birds and violets of the woods.

After the first flush of reviving life had passed, there came a pageant of golden green that brightened the gray of the Beech Woods and gave a setting of rarest beauty to the gray-blue boles of the trees.

Few trees there are that approach the incomparable beauty of the beech bark. The buttonwood with its marvellous browns and creamy white and green, is perhaps the only serious rival. From the pale gray of the young whip beech to the sombre green of the patriarchal tree there is an unending variety of colours. Upon the smooth bark nature has laid her colours with a subdued yet wonderfully subtle touch. There is nothing extravagant or loud about the colouring, but something infinitely restful and harmonious. No two are exactly alike in form or mark- 


\section{THE BEECH WOODS}

ings, no single tree is destitute of some individual touch. Here we see a giant rearing its head far above its fellows, straight and clean of limb, stroked with a mammoth brush nearly to its top. Now we meet a sturdy cousin, strong of build, wide of girth, with limbs far spreading, low to the ground. Again we see the graceful rounded form of one painted in a dozen tints of delicate colour, with here a touch of blue and there a touch of purple, now a shade of green and even a suggestion of unobtrusive yellow, all rare and pleasing. Mosses and lichen cling to the older trees, often supplying the distinctive touch that beautifies some otherwise plain guardian of the wood. Out in the soft loam the beech trees sink their roots like giant fingers clutching the earth. The elemental forces may wreck their tops, but seldom does it loose that splendid grip.

The Neighbour came to the woods one May day when all nature was busy performing her wonders. A chipmunk who had his home under the stump by the gap waited in silence until he came 

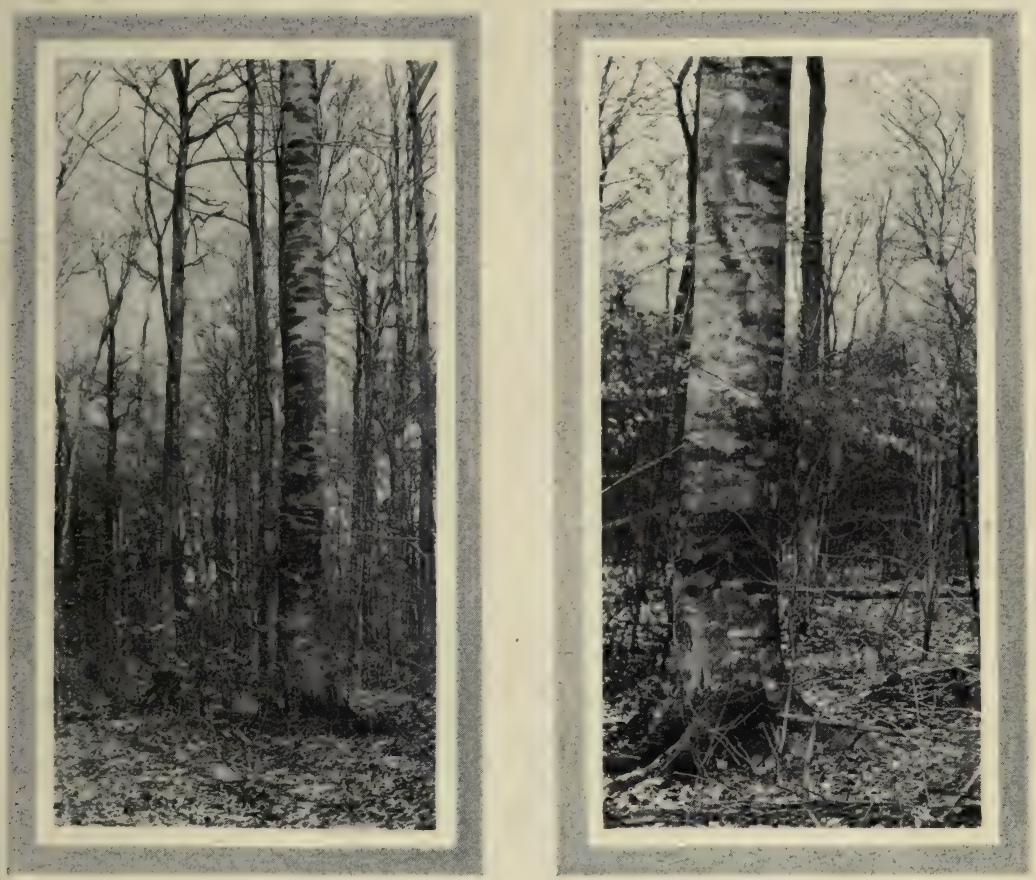

Nature has Painted the Beech with a Variety of Delicate Tints 

within three paces, then disappeared in his hole with a chattering squeak, to reappear almost instantly on the opposite side. A little way beyond a yellow warbler perched in the branches above startled him with a vigorous song. This was at the full tide of the mating season of the birds, the season of promise of love, hope and home-making. The Neighbour sat down beside the solitary chestnut which stands near the path, to watch and learn the many secrets of the woods. A saucy red squirrel discovered his presence and then and there began a dissertation on the virtues of mankind in general and this one specimen in particular. As he grew louder in his protests he became bolder and approached by little runs, with hind parts flat and raised on his forepaws. His eyes sparkled with mischievous fun, his tail quirking and jerking in accompaniment to his spasmodic utterances. He scolded and chattered and scoffed, then suddenly turned with a squeal of alarm and ran up the tree, where he remained to scold from safer distance. 


\section{THE BEECH WOODS}

Farther along the path the dogwood was a bower of white, and its strong perfume filled the air, blending with that of the flowers beneath and the apple blossoms which came floating to the woods from the orchard near by. The mandrake with its umbrella-like top crowded the open side of a little knoll and the budding bellwort grew thickly about. A brave jack-in-thepulpit stood facing a company of trilliums, some white, some red, and all attentive, while a cluster of violets near by listened with rare humility. Somewhere unseen, perhaps Pan was playing the music of this woodland service -who knows?

Returning homeward this day the Neighbour started a whippoorwill at the edge of the woods, which revived old associations connected with this bird. At the time of life when the Neighbour as a boy was just tall enough to peer over the fourth rail of the old snake fence by the woods, "Summer" was proclaimed by the first call of the whippoorwill, and this in turn was celebrated by the removal of boots and 
stockings for the glorious space of two short hours. How good the grass and the warm ground felt to the bare feet, but how hard the lumps of earth hidden in the grass, and $\mathrm{O}$ those thistles! As the days grew warmer the hours for "running barefoot" were increasedby permission, very often by stealth, and the whippoorwill was known to arrive long before its regular time. But this was in the days when the Beech Woods was suspected as a refuge for wild animals, and only the outer fringe visited by day and passed with forebodings by night.

Now as of old the swallows have returned as if by magic out of the limitless blue above the woods and are swooping and diving in their accustomed place. No one saw them arrive: no one ever does. They just appear as if they might have been there all the time, but just out of sight. They are the epitome of winged delight, flying often for the very love of it, tireless and ever graceful in their flight. They gather their food from the air, living on flies and insects of different sorts, 


\section{THE BEECH WOODS}

but with such delightful abandon do they seek their food, one would suspect their endless journeyings were for the sheer joy of it.

On a certain May morning that threatened rain the Neighbour found the Beech Woods melodious with song and alive with industry. Warblers of many varieties were about, searching among the branches and on the ground flicking over the leaves for food. This was a fairly sure sign of rain. The beautiful Blackburnian warbler, darting hither and thither from branch to branch along the border of the creek, flashing his rich orange and black plumage, enlivened the scene. Occasionally he stopped long enough to give forth his high-pitched, attractive song. Perched on a branch in a budding basswood tree, like a jewel in a setting of pale silver green, a scarlet tanager meditated between bursts of cheery song. His brilliant plumage seemed almost out of place in these northern woods, and suggested another world of great-leaved palms and exotic plants and vines. A saucy little house wren, 
in her hurried search, came suddenly upon the Neighbour, and after sizing him up with one eye through a chink in the roots of an upturned tree, decided he was quite harmless, came around quite close and talked in a familiar little chirp. Birds of many species mingled together searching for food on the ground and in the branches of the trees. Their varied songs blended in a continuous chorus of joy. And what a scene it was at this time when the whole woods were breaking into leaf. The long, glossy, russet-jacketed buds of the beech were unfolding in fragile pairs of silver-green loveliness. In the light of the morning sun the delicate transparent green forms, fringed with silver hairs, seemed to cast a faint radiance about them. On a few of the trees, now further advanced, the beautiful blossoms appeared like little balls of red and yellow silk, adding their colour to the general scheme of tinsel and lace.

Beneath the filigree of foliage the leafy floor of the woods showed groups of tall white trilliums, while mossy 


\section{THE BEECH WOODS}

banks glowed with a profusion of violets of every variety. By the bank of the creek, nodding in serried ranks, grew the Solomon's seal, and further on the belwort, with its cornflower yellow bells, seemed vainly trying to fill the open spaces between the trees. On the very edge of the creek bank, still further along, as if to perpetuate some wild wave of the floods that swept down the creek in years gone by, a mass of foam flower topped the crest and went rippling down the side in little waves of white.

Just here a solitary crow came sailing overhead, and catching sight of the Neighbour, circled around and gave two harsh caws, which were immediately answered by its mate far back in the woods. He continued to call and seemed to say, " Come here, come here." There was something he did not understand about this animal dressed in the garb of the woods, so he called his mate and alighted on a branch high overhead. Presently he came down closer and closer, peering first with one eye, then with the other, while his mate, 
arriving, joined in the investigation. The Neighbour did not stir, and they came down within thirty feet of where he sat. Farther than this they would not come, but rested there to observe with outstretched necks and many side glances every movement of this stranger. For a space of ten minutes thus they watched, satisfying their abundant curiosity and allaying their vigilant alarms, then silently took themselves off-passing the whole thing up, as it were.

Up the creek a piece where the old fence jogs its way through a thicket of young beeches, he met an old friend, but a stranger to the Beech Woods, being only a transient visitor on his way to the far North. There he may be heard beside the trail and out on bare brulée singing his sweet, refreshing song. The little white-throat, the friend of the prospector and the packman, cheering their lonely vigil with his song as they have translated it, "Hard times, Canada! Canada! Canada!"

Now another sound came from a knoll just beyond the thicket. Who 
has heard it without a thrill? Thud, thud, thud-thud-thudthudthudthud! A partridge was drumming somewhere on the knoll, and the Neighbour tried to see how near he could get to the old fellow before being discovered, and started warily forward. After crossing a small stream the edge of the thicket was reached; then extra caution was exerted by crawling along the ground. Foot by foot he went to the crest of the knoll, but no stump or log appeared with the drummer. A cottontail started out beside a $\log$ and went over the side hill in hurried jumps. Here he rested and waited for the partridge to drum. But there was no sound, only the woodthrush entertained him the while with a full repertoire of songs and a squirrel, discovering him, sat on a fence rail near by and started a subdued scolding. Evidently the partridge had taken fright and silently slipped away. Now a gentle patter of rain started on the dead leaves and the woodthrush poured forth the full beauty of his flute-like voice. No rarer, sweeter music was "ever heard in these woods. 


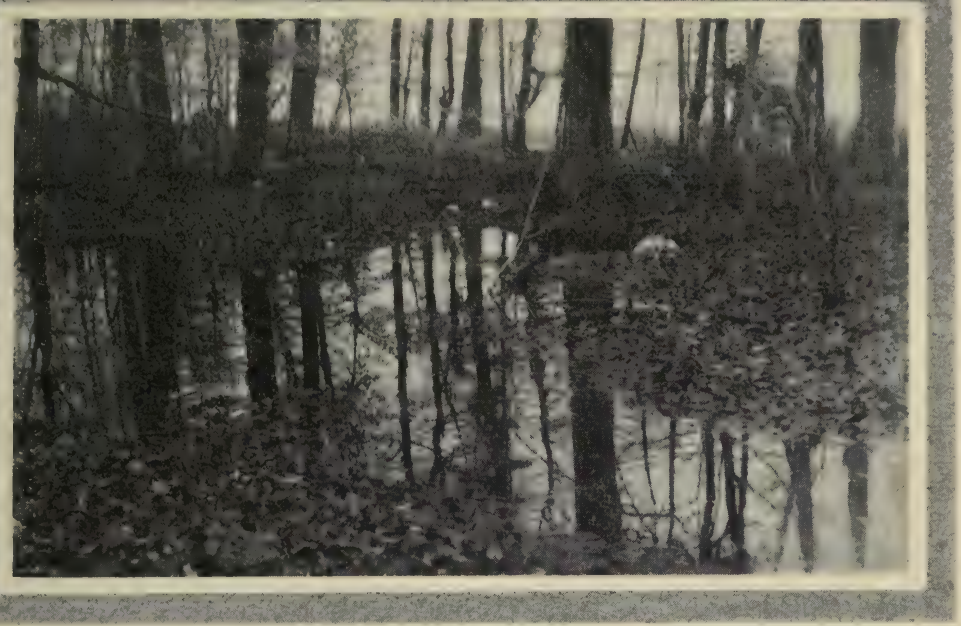

The Mirrored Pools of the Woods. 

During the night the rain beat down in heavy showers and the following morning the woods had changed as if by magic. Not only was this to be seen upon entering them, but was apparent from some distance. The delicate buds of yesterday were now unfolded in perfect young leaves of darker green, having fewer silver hairs upon them. New flowers had sprung up in the night. Anemones or windflowers appeared where only violets grew yesterday. The creek, now swollen by the rain, ran in many eddies and small channels in the creek bottom, forming numerous tiny islands between its banks. Each isolated bit of land seemed to favour some one kind of flower, for here the violets took possession of one and there the mandrakes completely hid another, while near the shore the tall red wake robin bravely faced the rising flood.

By the great elm stump now surrounded by water a pair of muskrats were enjoying their morning meal of grass and vegetable roots. They swam energetically from island to island, 


\section{THE BEECH WOODS}

using their flat tails to propel them along by waving them from side to side. Often they stopped to nibble at the dead limbs grounded on the banks of the stream, evidently finding sustenance in the lichens on the bark. Nature has fitted them well with their brown coats, making them difficult to distinguish from the brown roots and debris in the stream. Presently they started off up the creek, evidently making for their home in the bank of the old dam. Swimming steadily, submerged except for the tip of the nose, they left no wake in the running water as they disappeared around a bend in the stream.

Approaching the fence by the thicket the Neighbour listened for the partridge and was rewarded presently by the familiar drumbeat coming from the same direction as on the previous day. He carefully went forward to the hollow near the foot of the knoll and waited. When just about to advance still further the beating suddenly started, and to his surprise, there in the shrubbery, half way up the knoll on a decaying log, was Mr. Partridge. 
With head outthrust, his whole body tense, he started to beat, bringing his wings down sharply on the log, slowly at first, then in rapid succession until they blended in a booming whirr. Because of his natural colourings he easily eluded the Neighbour after he had stopped drumming, but a clean space about the log where the leaves were fanned away by his wings showed clearly his favourite drumming-place. Disappointed at not getting on better terms with the partridge, the Neighbour tramped around to the east and here witnessed one of the rare comedies of the woods which fully compensated for the other ill luck.

Just outside, a pair of king birds were building their nest in an apple tree, which was just breaking into bloom, but not sufficiently so to hide their prospective home. By many trips to the woods and fields they had gathered a quantity of soft grasses and wood fibre, which was taking on a rounded form through much pressing and fitting by the female. She arrived just now with a mouthful of nice downy 


\section{THE BEECH WOODS}

material, and with much care placed it in position. While she was thus busily engaged a pair of tiny yellow warblers sat on a high branch overhead and cautiously watched the whole operation with furtive glances. Just as soon as the king bird flew away out of sight the little warblers perked up. They became all attention. While one bird remained above to reconnoitre and dance in a nervous frenzy, the other swooped down on the nest and, grabbing a huge mouthful of the downy inner lining, flew swiftly to her nest in the alders with the long ends streaming out behind her. The king of the birds, the boldest and toughest fighter of the feathered folk, feared by all alike, being robbed by a yellow warbler! Can you beat it?

Thus the life of the Beech Woods goes on in this season of promise. Thus since the earliest "Johnny-jump-ups" pushed their tiny flowers through the dead leaves until the new foliage had draped the bare branches of the trees, the birds and the little people of the woods have filled each day with eager activity. As the sun descended and the 


\section{SPRING}

shadows became long, the tragedy and comedy of the day ceased. The mystery and wonder of a spring evening descended upon the woods. A predatory skunk, with his awkward gait and his slow, deliberate movements, stopped at the edge of the clearing and sniffed the air. He sat and looked in the direction of the Neighbour's house : but his was not the strange surmisings of civilized ways in which other forest creatures indulged, for he had visited too many farm-yards and knew the taste of young fowl. A rabbit with big, sleepy eyes hopped out in the path to sit with one forepaw raised and ears thrown back. It seemed to come from nowhere, so silently it moved and as silently disappeared among the leaves. The little owl sat in the doorway of his home in the hollow tree, awaiting the darkness, when he would go forth like a gray shadow to the open fields.

The woods seemed to sleep, the whole world sought rest after a day of happy activity, and little disturbed the great quiet except a sleepy bird-note now and 


\section{THE BEECH WOODS}

then and the boom of the bittern down by the pond.

Spring had come to the Beech Woods, and the trees and the earth had responded gloriously to the call. The Neighbour had felt the magic of it also and had become young once more. The poet who lived up the road knew it well when she wrote:

If one might live ten years among the leaves,

Ten-only ten - of all a life's long day, Who would not choose a childhood 'neath the eaves

Low sloping to some slender footpath way?

To learn to speak whlle young birds learned to sing,

To learn to run e'en as they learned to fly; With unworn heart against the breast of spring,

To watch the moments smile as they went by.

Enroofed with apple buds afar to roam,

Or clover-cradled on the murmurous sod; To drowse within the blessed fields of home, So near the earth-so very near to God. 


\section{SUMMER}





\section{SUMMER}

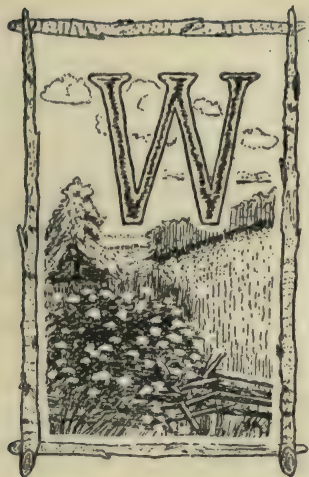

HEN the elderberry blooms and the young corn is growing green and the sweet chestnut is in blossom and the June berry is ripe and the under vines in the pea field are yellow, Summer walks in her prime. There is no sudden change, no noisy clamouring of Nature, but a gradual merging of Spring into Summer days.

Now the call of Spring had been answered in countless hearts of beasts and birds and human kind. The season of promise, of reviving life, the season of restless longing for the open road, had gradually been absorbed by the business of life, the dream of youth become the cosmic reality.

Now has come the season of work and growth before the harvest. Such ceaseless hurryings to and fro from 


\section{THE BEECH WOODS}

sheltered nest to open fields, and from orchard trees to hidden fledgelings in the nest, such an array of hungry mouths to feed is ample proof of the season of work.

The beech leaves have taken on a deeper hue of green and show a fine gloss. Beneath the thick foliage is a plenitude of cool shade which now is appreciated, since the sun's warmth has increased to Summer heat. Once you enter the door to the south of the woods, the varying bird-notes re-echo among the green arches in continuous rounds of vivacious song, different in variety to that of the birds of the open fields. The bobolink, while hovering above the hay field, literally fills the air with a profusion of liquid notes, so refreshing and beautiful it would seem hard to find a rival songster, yet from a tree-top in the thickest part of the woods comes the song of the veery, running his perfect cadence in rich flute notes. The song-sparrow sings from his fence stake by the roadside, and just inside, the ovenbird at regular inter- 


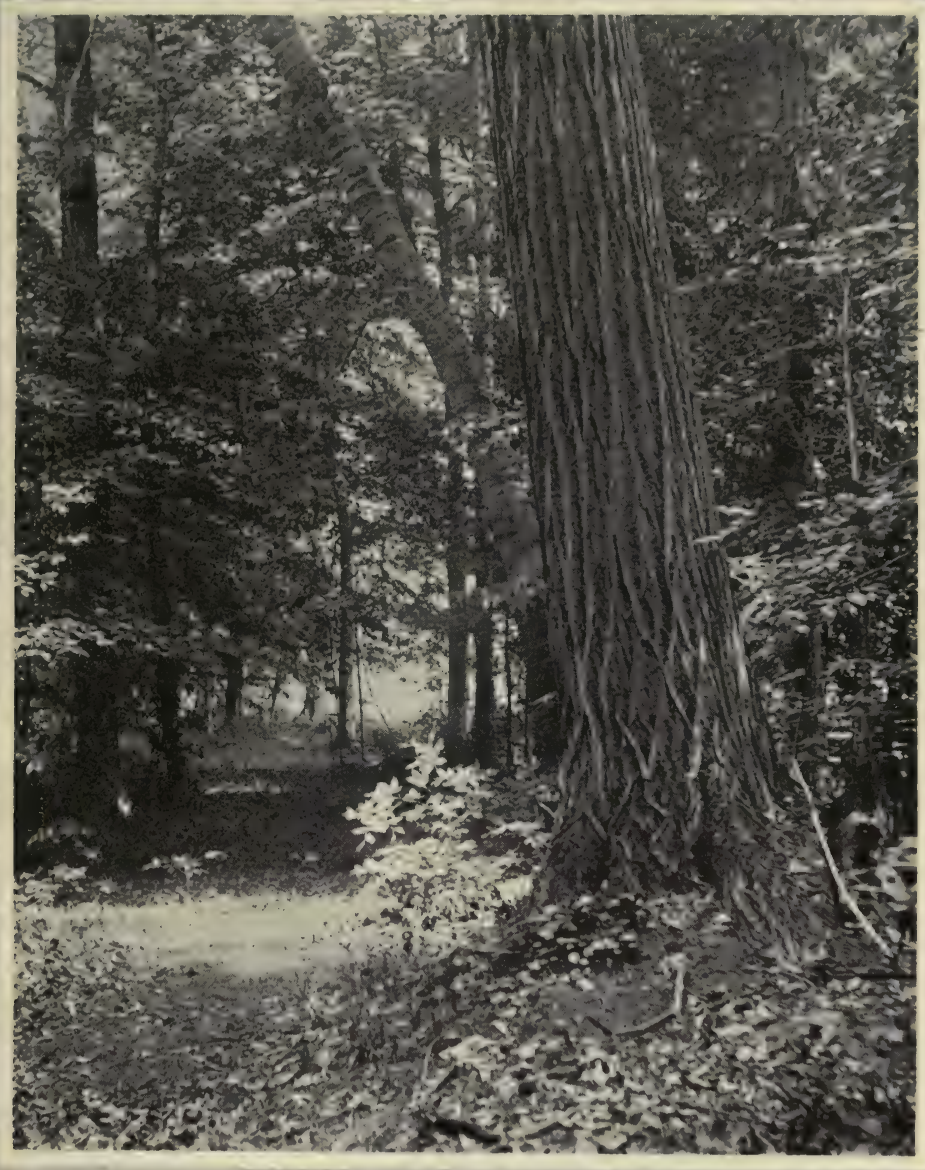

The Giant Chestnut 



\section{SUMMER}

vals makes the old woods resound with his "teacher" crescendo.

The sky lark and the oriole, blue bird and meadow lark swell the feathered chorus from the fields and orchards, while from the cover of the trees the woodthrushes, flickers and warblers all contribute to the festival of song.

The beech sprouts underneath the trees have now developed their twin leaves and no longer may be eaten. The beech nuts in the rich bed of leaves, if missed by the squirrels and birds in the Spring, send down a root in the soil, and the nut itself is raised on the stem almost in its original state, later developing into a young tree. These tender shoots retain their nutty flavour and are mighty good to eat, as the small boy knows.

Along the path beyond the big chestnut, where here and there splashes of sunlight illuminate the bark of the leaning beech and fall on a bank of green moss, a scent more luring than anything else at this time of year is first encountered. The path leads us half-way into the open to meet the dis- 
tiller of that delicious scent, and here they grow-wild strawberries hiding in luscious clusters, ripe and red in the grass among the stumps of the clearing. A hatful of these delicious beauties is worth travelling many miles to obtain, and the fun of gathering is no small part of the pleasure, for as each hidden cluster is discovered there is always felt that instant thrill of surprise, and the welcome given the bearer of such a hatful is most spontaneous, to say the least, especially if they are the first of the season.

On the other side of the woods, near the western fence, the June berry tree is loaded with its purplish-red fruit. Nearly all the birds of the Beech Woods seemed to be feeding upon this favourite fruit; cedar waxwings in their smooth garb were there, and redheaded woodpeckers kept up a continual procession to and from the tree. Orioles and robins, flickers and black birds all congregated to feast and fetch for their hungry young. It is said the Indians in days gone by looked upon the June berry as an important part of 
their food, gathering and drying the fruit in great quantities for winter use. After the berries had been gathered they were mashed to a pulp, spread out and dried in the sun, no doubt making a very primitive but edible dish and one which would go nicely with venison.

Along the fence, not far from the June berry, growing in stately beauty, a solitary columbine lifted its goldenred flowers above the surrounding plants and vines. Bees and butterflies hummed and flitted about seeking the abundant sweets, and a ruby-throated humming-bird paused before each flower in turn collecting the insects from the long, delicate spurs of the flowers. Each in itself was a perfect picture. The poise and delicacy of movement of the humming-bird, with all its bright colours, is most fascinating to the eye. The columbine growing about these woods seemed never so plentiful as to lose that rare distinction of character which makes it a pleasure to find.

Summer had now brought its last 


\section{THE BEECH WOODS}

migrants to the Beech Woods and flowers of the season had come to replace those of the awakening days of Spring. The grass has grown longer in the hay field and the young clover is now a mass of red and white. The days soon followed when the song of the mower thrilled the morning hours and often far into the dusk. The sweet scent of the new-mown hay floated to the woods at evening, mingling with the scent of ferns and flowers. The poet living up the road, in her poem, " The Hayfield," part of which is quoted here, tells most exquisitely of the passing of the grass:

With slender arms outstretching in the sun

The grass lies dead;

The wind walks tenderly and stirs not one Frafl fallen head.

No more they part their arms and wreathe them close

Again, to shield

Some love-full little nest-a dainty house Hid in a field.

For them no more the splendour of the storm, The fair delights

of moon and star-shine, glimmering faint and warm

On summer nights. 


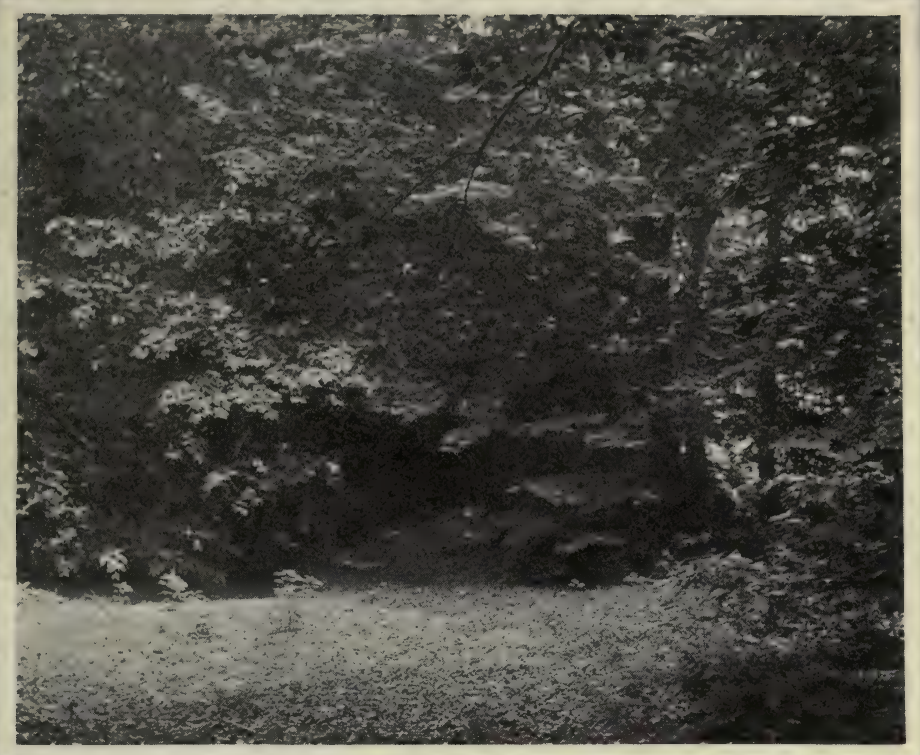

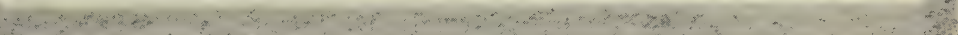

The Entrance to the Wood-Path 



\section{SUMMER}

Their little lives they yleld in summer death, And frequently

Across the field bereaved their dying breath Is brought to me.

The Summer solstice had come. The long hours of a June day were filled with light which filtered here and there through the leaves overhead and rested on the carpet of the woods, illuminating each decaying leaf or twig or lacey frond, ever moving, ever changing from sunlight to shadow and from goldenyellow to brown and from brown to warm violet. Splashes of sunlight transformed the straight young beeches from gray poles to golden shafts and left the upper reaches of the trees a shimmering sea of transparent goldengreen against a dome of blue. There in a quiet spot where the sunlight came to bathe the maple through the long hours of the afternoon, the trailing partridge berry grew and wreathed its vines about the roots of an old pine stump. The air was laden with the redolent aroma from its creamy-white and pink flowers snuggling in pairs among its shiny green leaves. This spot, within sound of the babbling 
creek and invested with all the beauties of nature, might have been a bit of Arcady transplanted in these woods.

Down in the little forests where the whip trees grow in clumps, the wood folk have their paths, highways on the forest floor. Here their trails lead through miniature aisles, past the huge trunks of larger trees-mileposts of their journeys, where they travel to their foraging ground or wander in their endless quests. Here the partridge cautiously leads her brood through the chequered dimness of the beech knoll, past the old pine stump to where, in the spring, her mate thrilled her kindred with his drumming.

The woodchuck digs fresh tunnels and heaps the red earth beside his den, a mound on which to watch and rest in the sun. He is a wise little fellow, for he has chosen a spot where the sun reaches down for many hours a day, and yet the woods are thick about him. After his long winter's sleep he relaxes in the comforting warmth and grows fat.

The cottontail and the wood mice 48 


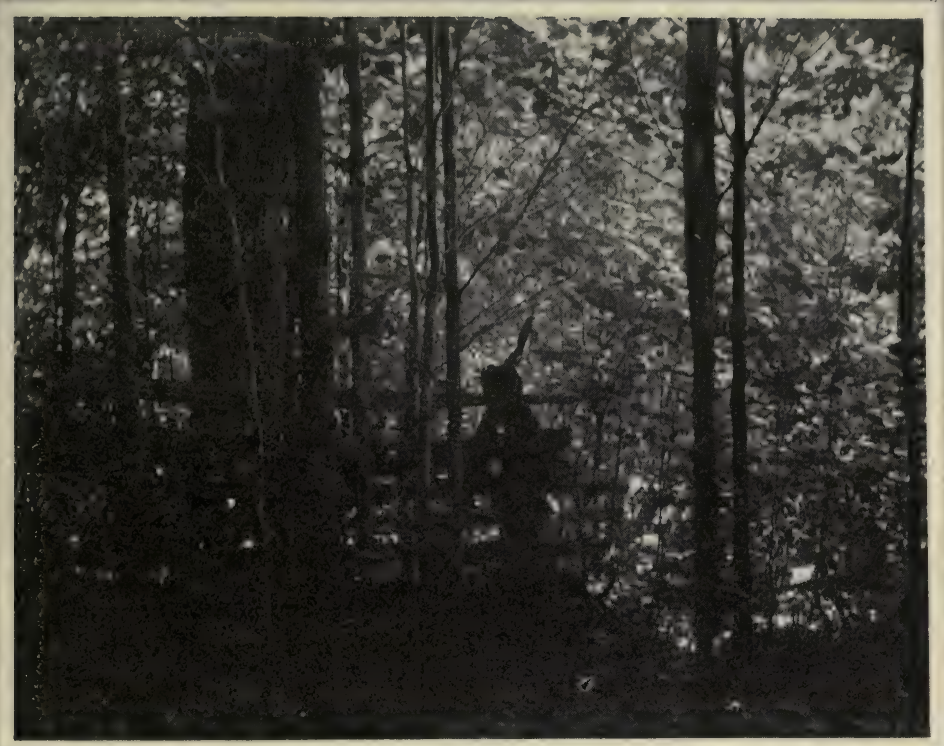

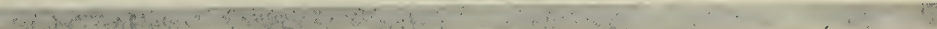

Down Among the Whip Trees the Wood Folk had Their Paths. 



\section{SUMMER}

await the protective cover of the darkness before they come forth to haunt these endless trails, but the gray and black squirrel keep the leaves and litter of the woods constantly stirred up in their favourite foraging grounds, finding now and then a stray nut overlooked from last season's crop. Often through the day their harsh scoldings can be heard from the large maples as they whisk about the limbs in friendly play, or more often when family quarrels disturb their domestic happiness.

Somehow the woods seems quieter as the Summer draws on. The army of transient warblers, which passed through early in the season for more northerly climes, took with them that animated chorus of song the woods now lack. But other and more important business has come to occupy the time. As if to strengthen this supposition, there comes from the pines to the west of the woods a strange babble of sound, a sort of choking gurgle mingled with eager caws. The old crows feeding their sturdy young, who 


\section{THE BEECH WOODS}

take their food with much noise and gusto. One day an old crow left on guard near the pines discovered the Neighbour moving beneath the rookery and gave the alarm, eawing harshly and circling about. From all parts of the wood and even the neighbouring woods came the answering calls, and soon there were dozens of agitated friends adding their cries to the bedlam of noise. A hawk, taking alarm, added his harsh screams to the general confusion, and circled away to a quieter part of the woods to await developments. The Neighbour kept himself hidden in the thick undergrowth, and suddenly they moved off to the centre of the woods, where they had seen him the day previous, and broke out afresh in a wild babble of alarm. These spasmodic uproars continued for over an hour before they finally grew quiet and dispersed to their home woods.

Frequently in the early mornings the old birds varied their diet by visiting the Neighbour's corn field when the corn was just sprouting, scorning the clownish scarecrow in the cocked 


\section{SUMMER}

hat and systematically digging up the corn rows. Now that this luxury was no longer to be had, they weren't above robbing the bird's nests, and a robin's nest in the low growth of the beech knoll bore mute testimony to a recent visit. The blue eggs were scattered on the ground, each bearing the telltale holes made by the robber's bill. Probably a mischievous red squirrel had taken a hand in the affair also, for the nest was loosened and hung at a slant. No doubt arriving after the eggs had been destroyed, he must needs put the finishing touches on the depredation.

Just over the fence from this spot a red-eyed vireo had hung her nest on the swaying branch of a young beech and was sitting contented and happy, not knowing the tragedy that awaited her brood when they should hatch. The cowbird neither builds a nest nor rears her young, but lays her eggs in the smaller bird's nest, and here she had deposited one. When the young vireos hatched, the impostor, being the larger, would require more attention 
and take most of the food, the smaller birds eventually dying of starvation. The vireo followed each movement of the Neighbour, and protested with petulant scoldings when the intruder's egg was thrown out, but happily a tragedy was averted for the little family.

The creek, which had swollen with each successive flood in the spring and covered the flats, collecting on its downward journey all sorts of debris and depositing it at the cross fences, now grew daily narrower and more shallow. No longer it raced through the narrow channels murmuring joyously the while; then expanding itself in a broad, smooth sheet moving silently over ruddy bottoms to slip noiselessly into the deeper pools overhung by the spreading branches of the trees. From these leaf-bottomed pools, now deep with shade, now bright with light, it no longer came wimpling and streaming out into the grassy flats of the bush meadow, to pursue its sinuous way in a semicircle back to the woods again. 


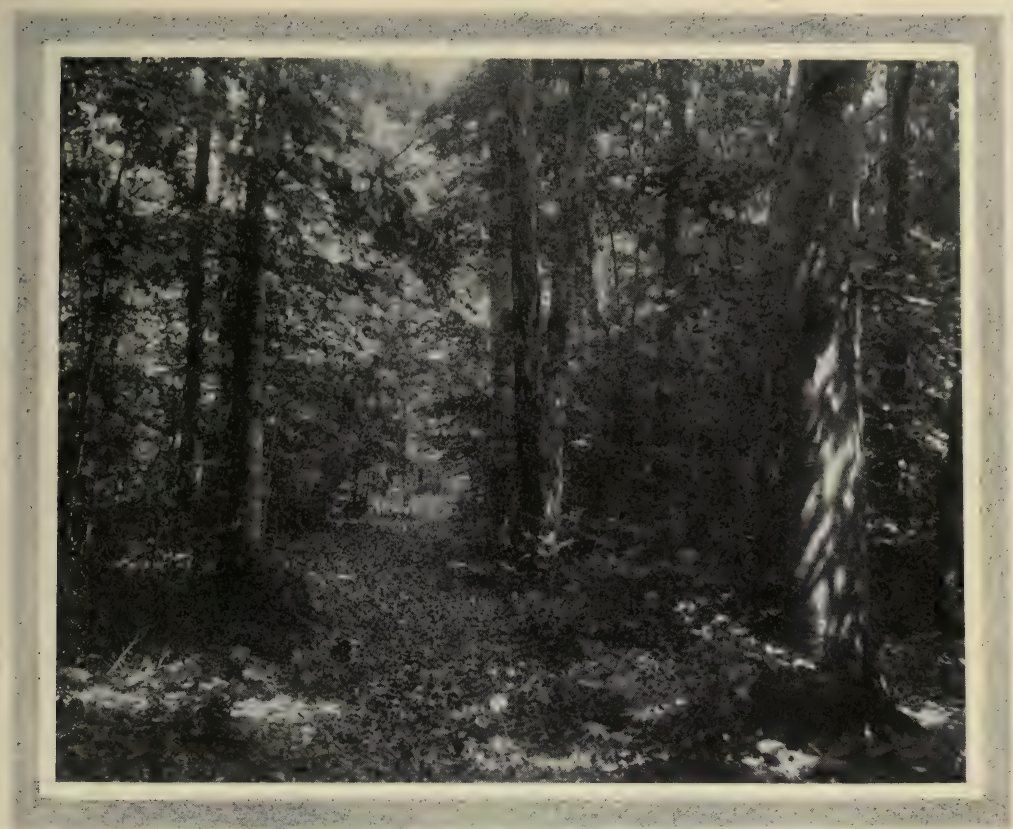

Down the Gray Aisles of the Beeches. 

In the days that followed the Spring chorus, the pools and eddies began to team with all subaqueous life. Now the " pollywogs" had grown from little black specks to large gray minnow-like creatures mostly head. The scooters and shiny water bugs increased in multitudinous numbers, and the larva of the dragon fly covered the bottom of the creek like little bits of decaying wood. Basswoods and elms grew plentifully in the flats, spreading great roots into the stream, and occasionally a black ash stood on guard at some selected spot. An upturned basswood lay full length upstream, the current running by its side. It was now the favourite resting place for black-winged dragon flies, and here in the sunshine they flattened themselves on the bark to bask in the sunshine.

Farther up stream an old elm, with wind-wrecked top, stood in desolate isolation on a little island in midstream. Upon its hollowed stub the flickers came to sound a deep bass tattoo, which echoed through the woods, and which they evidently enjoyed. Up 
by the pond there was still a trickle of water, but the lower bed of the creek was dry. Here the jewel weed grew in a solitary group, flashing its beautiful flowers to all the bees and butterflies that passed. Many varieties of grass fringed the pool and dipped their long leaves in the friendly water. How well Nature protects her aquatic life is here shown, for a young dragon fly, still in the larvæ stage, allowed itself to be covered with the silt of the pond and resembled a submerged chip more than anything else. When touched with a stick it rolled over and appeared to be dead. A second gentle poke brought no life, but a third was the signal of discovery apparently, for it suddenly came to life with a scoot and disappeared in the weeds.

Down where the creek runs between banks of clay the remaining pools are fringed with mud and show many tracks of animals and birds. The raccoon's broad imprints are unmistakable, and beside them the muskrat's trailing tail had left a line between its wandering tracks. Delicate impres- 
sions of birds marked where they had come for a drink or a bath, and tiny irregular patches showed where the wasps had secured the material for their houses of clay. Many weeks would elapse before it would again race joyously through its winding bed to join the larger streams in its journey to the great Falls of Niagara.

The red moon of August came, with it a long period of Summer drought and caused great cracks to open up in the parched ground. The mud at the edge of the pond became baked into little saucers, and the leaves of the trees beside the road were covered with a thick layer of dust. The sun rose each day in a cloudless sky and cast its lurid flame upon the land, scorching the grass and wilting even the willows by the creek. But now one day it appeared within an iridescent circle with four sundogs to watch its fiery path across the arc of heaven. Three successive days this occurred. Each day a new circle was added, while the air grew close and the whole horizon line danced grotesquely through the radia- 


\section{THE BEECH WOODS}

tion of the heat. Not a leaf in the Beech Woods stirred. Scarcely a bird note broke the apathy of the sultry days. Now little whirlwinds started seemingly from nowhere, catching up the dust and dead grass and whirling them high in the air, making the branches of the trees twist and thrash about. Little vagrant breezes began to stir among the leaves, touching a branch here and passing on to one there, whispering of greater things to come.

Now on the horizon to the Southwest a great anvil-shaped cloud lay half-obscured in the haze, and thunder caps pushed up their rounded white domes on either flank. The little breezes that were playing about joined hands, and with one accord blew from the East, while the clouds in the West gradually rose higher and higher towards the zenith. The flicker called repeatedly from the woods, giving his " rain" cry, and the tree toads voiced their welcoming song. Song sparrows and robins woke to life and added their 
rejoicing notes after days of comparative quiet.

The thunder caps on the flanks of the great cloud swung to the North and to the South, while the vanguard of the great anvil slowly pushed Eastward across the sun. Local conditions rapidly changed. The winds, which had been coming in gusts, died down and a deadly calm prevailed. Birds flitted uneasily from place to place chirping in fright and seeking shelter from the storm. High overhead a flock of gulls flew Westward to meet the coming tempest, and the purple martins raced joyously over the woods, their noisy twittering contrasting strangely with the ominous quiet.

A dull roar, which ever grew louder and louder, approached the wood. A long low rack of clouds which swept rapidly forward in a line was followed by an inky wall, the green of the trees showing pale against it. Suddenly the gloom was lit by a blinding flash, instantly followed by a reverberating crash of thunder. Great drops of rain came driving through the dust-laden 


\section{THE BEECH WOODS}

wind, and then, as if the heavens opened up the flood gates, the storm broke and torrents of rain beat downward wave on wave. The rattling crash of thunder punctuated the steady roar of the storm, and went rumbling away and circling back. Before it died out, the heavens were split with another deafening peal which shook the earth. Gradually the storm settled into a steady downpour, which washed the trees and grass and filled each little river way with a foamy torrent. The thirsty ground drank and drank of the reviving flood. Gradually the rain spent itself and stopped, but not until the last cloud had lifted overhead.

The sun broke forth again upon a new world; all clean and refreshed. In the East the rainbow formed in all its

- glorious colours, and the birds began to sing and one by one poured forth his full heart to the new world. The old pond had been filled, and the creek for the time being babbled on its accustomed way, carrying much debris on its foamy surface.

The woods were washed and the leaves shimmered and sparkled with 58 

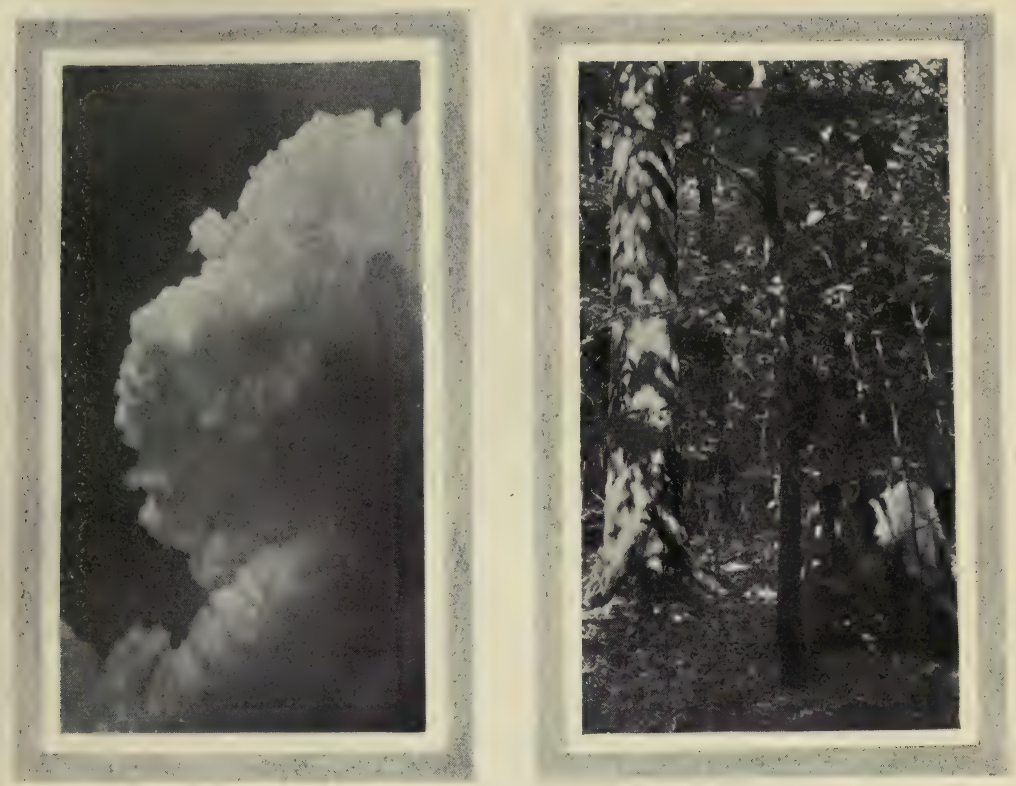

The Vanguard of the Storm Pushed Slowly Across the Sun.

The Partridge Berry Grew About the Old Pine Stump. 

the water drops still clinging to them.

In the great battle just passed the woods had lost one of its number, but not a beech, for the beech tree is immune to lightning. Over near the eastern fence a tall pine had been struck and cut clean in two, and the whole upper part thrown some distance from the remaining stub. Great chips lay strewn about and the scent of fresh pine filled the air.

Between alternate days of stereoscopic clearness and hazy sunshine, August slowly drifted to its close. Across the golden stubble, bright with light, the woods stood out in bold relief, and from the distance just discernible the old red maple's crimson flag proclaimed the Summer's end. The bluebirds flashed about the fields in straggling flocks, adding their melancholy cries and restless flights to other hints of early Autumn. The families of feathered folk in the woods were full grown, and already home ties were broken and the nests deserted. The woods were alive with young birds testing their voices and trying their wings for the long flight Southward. 

AUTUMN 



\section{AUTUMN}

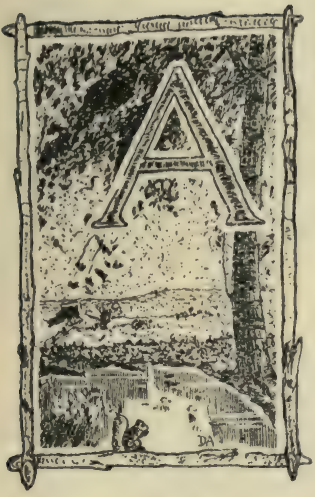

GREAT contented hush pervaded the Beech Woods and adjacent fields this Autumn afternoon. The season of fruitage and fulfillment that slowly drifted down the September days seemed to pause in wonderment at all the opulence of fields and woods. Over the corn field stretching away toward the West a golden opalescent light flooded the open spaces and cast long mellow rays in among the trees, lighting up the mosaic of the forest floor and resting warmly upon the gray beech boles. Myriads of dancing insects filled the air and flying beetles winged their uncertain flight here and there among the shocks in endless journeyings across the sun. Faintly glimmering gossamer, now touched with golden light, 
now silvery in the shade, floated in the air or hung suspended from the drying tassels of the corn, softly illuminating the contented field with a fairy-like glamour.

Dimly discernible in the smoky haze that veiled its chequered slopes, the long ridge to the north appeared like an Autumn apparition fading away in the murky distance. Here the creek had its source and began its journey far up the slope, timidly winding its course through fields and woodland swales until it entered the canopied shade of the Beech Woods. Here, too, in days gone by the Redman pitched his tepee, hunting these forest trails and sending up his smoke signals that called a council of the tribes together or warned them of approaching danger. And down in the woodlands of the plain, to East, to South and West, and from the forest of the beeches rose the answering signals, while far away the eternal mists of the mighty Niagara wreathed upward, a constant token of the Great Father, Getchie Manitou.

Autumn had come again to the 64 

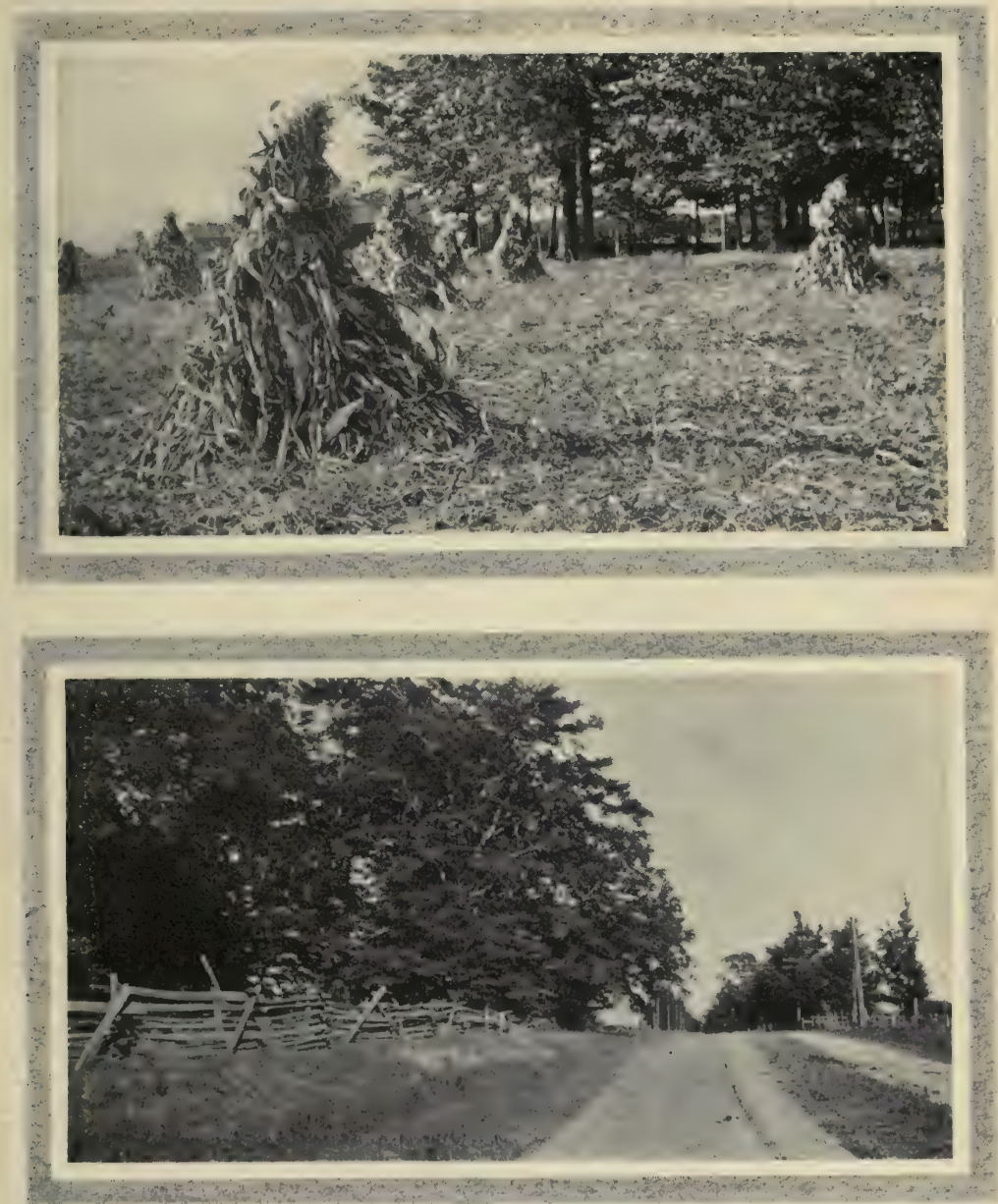

An Opalescent Light Flooded the Cornfield.

The Road to the South of the Beech?Woods. 



\section{AUTUMN}

woods, brushing the trees and fields with its wonderful colours, swinging its magic incense in the air, flooding the day with golden light, starting the subtle hum of music, and investing all the tranced hours with a touch of romance. Yet above the contentment and the hush, greater than the attraction of colour, more luring than the opalescent light, was this spicy incense of the Autumn air. Magical and mysterious is the potency of these pungent odours, so different from those of the Spring, and yet the call to the woods is the same. Perhaps the flowers of the Autumn have a more lasting and stronger perfume than those of other seasons, and grow more abundantly, if not in such a rich variety. The yellow goldenrod is everywhere along the fence rows and in the open, sharing the ground with the fragrant purple aster. And there is the old-fashioned everlasting with its old-fashioned redolent aroma, a flower of the dying year. These, added to the spicy scent of burning leaves, would seem to form 


\section{THE BEECH WOODS}

a foundation for all the Autumn odours that haunt the woods.

The migrants of the North now stop for a brief visit on the long journey southward. Once more the woods are enlivened with songs heard first in the early Spring. Bluebirds, which had been flocking for weeks about the fields, have already departed, but other flocks remain for a transient call. Each morning new birds are seen, while others have left during the night for their southern homes. The woodthrush, whose beautiful song cast a charm about the beech knoll all through the Summer, is heard no more. The catbird's sweet medley is also missed from the same thickets which now only are tenanted by the nuthatches. Of course, the partridge is still about with her mate and their full-grown young. What a wealth of beauty and richness their presence gives to the woods at this season as they scratch among the leaves or suddenly break the quiet and go booming away to the pine shelters. At one time these groves were the favourite breed- 
ing grounds for numerous flocks, but now only a few pair survive the hunters' guns. The flicker's call is heard, and the roadsides are alive with their numerous flocks. Goldfinches pass by in flashing dipping waves, twittering as they go from tree to tree. Robins are seen about the woods much more than at any other time of the year, and help to dispel the quiet that seems to lurk about at times. The hawks have no thought of departing yet for the South, and sail overhead in the warm sunshine for many hours a day. Often the noisy blue jay passes through, and if there are any strangers about or nuts to be stolen he will be there to give the alarm. The pair of blue herons who built their nest in an adjacent woods often come to the pond in the early morning to hunt for food and wait silently like reeds in the shallow water. But a restlessness unlike the Spring ambition impels all feathered creatures to be ever on the alert, anticipating the migratory flight, when they shall rise in the dim light and drift down the pathway of the skies. 


\section{THE BEECH WOODS.}

One afternoon early in October the Neighbour felt the call to the open and rambled across the fields, climbed through the rail fence in the lane, and stopped for a moment to gaze upon the scene that lay before him. Autumn's gorgeous pageant stood waiting in the mellow golden light. The polychrome of colour went rippling across the face of the woods in waves and splashes of russet, green, aureolin and red, while the wild barbaric flame of the giant maple rose above the canopy of trees like the sceptre of an Autumn king. Out in the fields a solitary hickory stood in livery of gold, cherry clumps were brushed with rusty yellow, and lowland ash turned a purplish tint. From horizon to horizon the panoramic pageant stretched in richest splendour and softly disappeared in the smoky haze of the dim distance. The lazy drone of insect music was borne in upon the senses, and the lonesome call of birds came from the etherical wastes above. This was a day when Nature seemed to softly doze, and dozing 


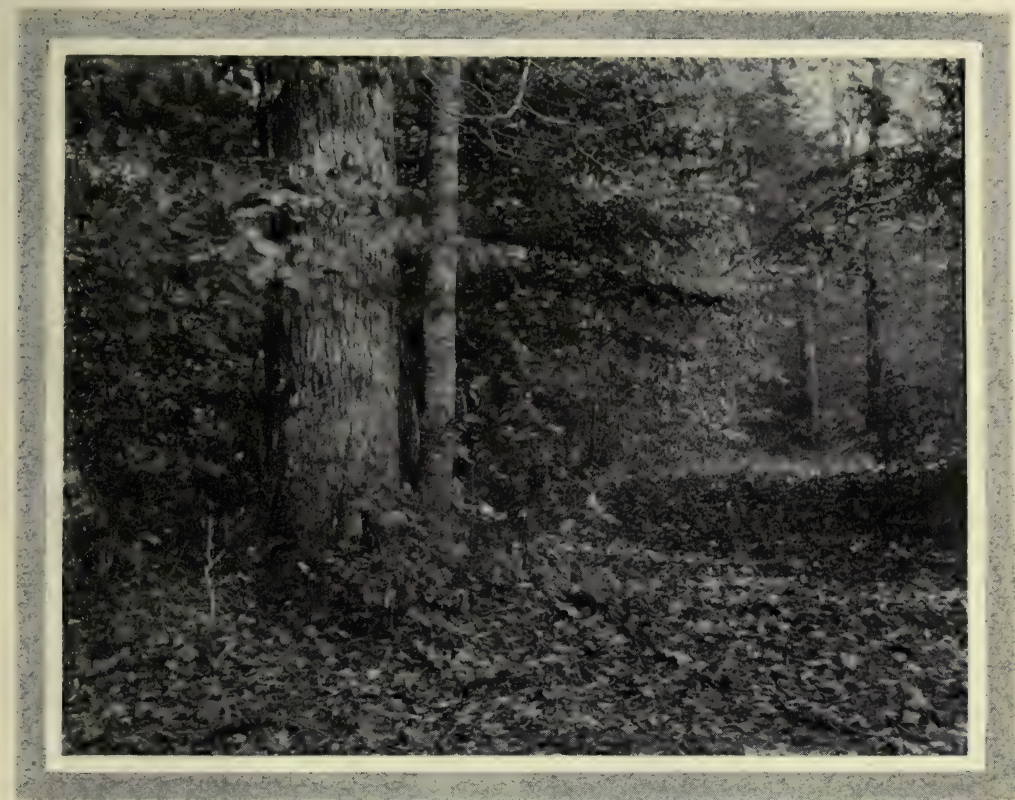

A Riot of Colour Went Rippling Across the Face of the Woods. 

dream of heaven, and dreaming wake to find it true.

The Neighbour sauntered down the lane toward the gap, passing fence corners crowded with goldenrod and others a purple glow of asters. How sweet the asters smelled, these " Asters of the Wood," with their beautiful contrast of colours. There seems to be nothing that just can fill the place of these sturdy flowers, so rich in colour and perfume.

Here a rather unexpected sight met the Neighbour's eye. Perched on a flat fence rail behind a stake sat Mr. Squirrel busily engaged with something he held in his forepaws. Indeed, he was so busy he did not see nor hear the Neighbour's approach until almost opposite him. He admitted his surprise by a loud squeal and charged down the fence toward the woods, but suddenly stopped and started back, barking and scolding as he came. A rail length away he hesitated, but finally, getting his courage up to the proper pitch, made a dash, seized something he had dropped in his hurried 


\section{THE BEECH WOODS}

flight, and with a great deal of muffled chuckling disappeared in the woods. The mystery was explained by the scattered remains of a chestnut burr on the rail where he had perched. The squirrel, with his natural foresight, was examining a sample of the lone tree near the lane to see if the crop was ready to cut; evidently it was nearly ready, for a few days later he could be heard singing lustily his harvesting song, while from time to time the burrs rattled through the leaves and landed on the ground below with a thud.

Through these days the red squirrel is business personified. No waiting until the burrs crack open and the brown nuts drop out. He takes no sporting chances with his gray and black kindred or the crows, blue jays, chipmunks, and the hosts of other harvesters. He cuts and sings and cuts again, then gathers the green prickly burrs and packs them in a hollow log or stump for winter use. When the November winds shake down the brown nuts he gathers more and adds them to his store, but prefers to hide 


\section{AUTUMN}

a part of these in numerous small caches in the ground, sometimes forgetting where he placed his precious food.

Along the path just north of the gap the Neighbour found the old sugar maple a flame of colour. Each bough had been touched with red and gold, shading to green on the inner branches near the trunk. Each species of maple was coloured according to its kind, standing in contrast to the green and soft gold of the beeches, as yet only beginning to show their colour. Here a single bough of maple, all aflame with ruddy fire, reached down nearly to the ground, while a few feet away a young water maple stood garbed in palest yellow. As yet few leaves had fallen to cover the dark russet of the old leaves, but red berries of the jack-inthe-pulpit grew plentifully about, adding their richness to Autumn's already abundant store of colours. Creeping vines were turned to a bright red, mingling with the leaves of trees, about which they were entwined. Over the fence in the centre where the hard 


\section{THE BEECH WOODS}

woods grew the thickets of young maple gloried in a cloak of brilliant yellow, illuminating all the woods about with the happy glow. The birches that grow hereabout were also trimmed in the delicate tint so becoming to their graceful traceries. So the Neighbour found the woodland paths this Autumn afternoon a fairyland of blended tints, until he reached the deeper shade of the pine trees to the north. Within these silent groves little change had come, except where the sprinkling of other trees broke the quiet greenness with their brilliant draperies. The Autumn days came softly treading with scarcely a sound to disturb these giant trees, who but a short season gone had held the noisiest of all the forest dwellers.

The wind that went whispering through the oats in June and idly lingered over August's golden stubble, now gleefully swept the fields in the days that followed. Each boisterous gust sent the brown nuts of beech and chestnut rattling down and drove clouds of leaves far out from the east- 
ern side of the woods like flocks of birds and covered the fallow ground with a layer of variegated colour. This first wind of Autumn is a playful thing, seeming to delight in loosing the glory of the trees and casting it about. It is an exhilarating feeling to be in the midst of the driving leaves and watch them racing and sliding down the wind currents, to be caught by another and lifted up and driven onward out of sight. Before this first wind comes and while the nuts are still upon the trees, is the time to gather the "beech mast." Back in those childhood days the youngsters, laden with poles, blankets, sheets, quilts or anything that was handy and could be secreted from the house, visited the Beech Woods, and the " easy climbers" sought out-trees having limbs within reach. The sheets were spread on the ground, and the fun began. The boys shinned up the trees and shook and pounded the limbs, while the girls below danced and shouted to the merry rain of nuts. Each spreading limb was relieved of its load, and the boys vied with each other 


\section{THE BEECH WOODS}

in seeing which special limb yielded the most and made the most noise when the nuts fell on the ground below. The rough husks were sorted out and thrown away, and the usual noisy discussion developed as to who should receive the largest share. But eventually this was settled to the mutual satisfaction of all, and the happy company frolicked homeward, each with a store of precious brown cubes.

The havoc of the wind is soon shown by the bare trees among those that yield their leaves only after the heavy frosts have sent them drifting down. The pools and the creeks were now filled by the rains that came from the East and hung for days about the horizon. From the time the creek resumed its customary course it seemed to attract attention from the woods. Leaves in dainty tints of every colour floated upon its surface or sailed gracefully with its happy tide. The goldenrod swung its heavy tops from the bank of the old pond and cast a gilded image in the mirrored surface. Here the asters grew in abundance with a 74 


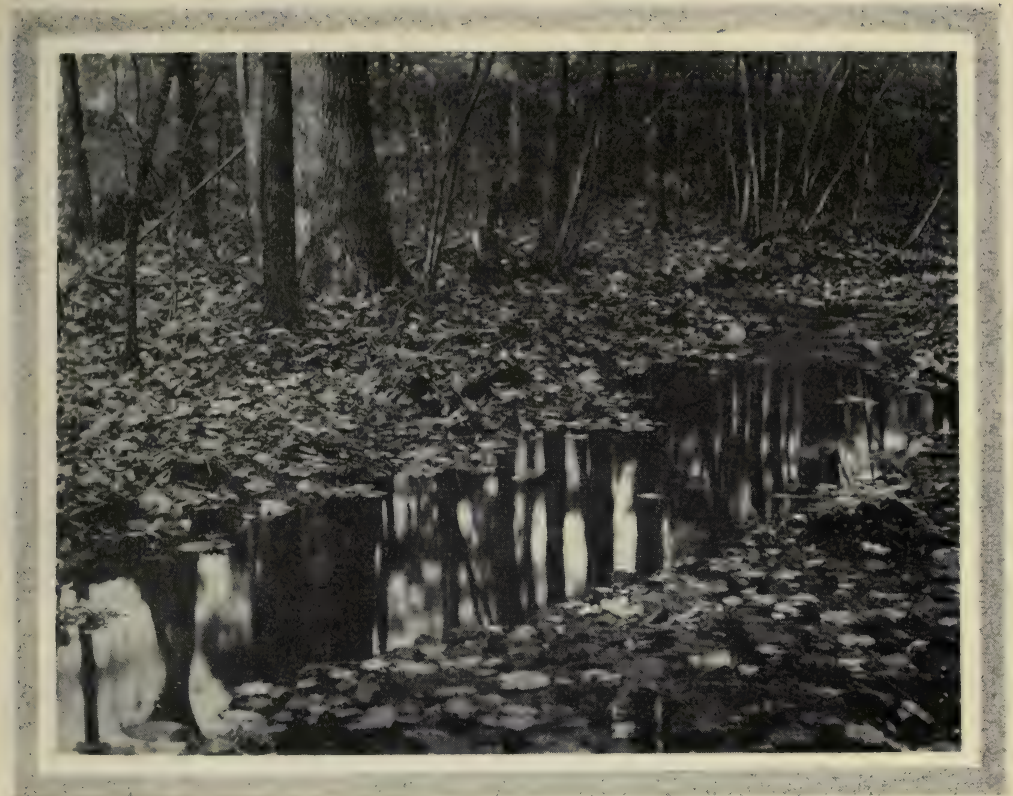

The Creek Once Mose Resumed its Customary Way. 



\section{AUTUMN}

variety of colours filling the cleared space to the western fence. The pretty little lilac flowers of the heart-leaved aster swarmed up the slope to the fringe of pines. Mingled with the mass of lighter flowers the pink and purple clumps stood out in beautiful contrast, while bees fairly swarmed about seeking the last rich harvest of honey.

All the fragrant flowers of Autumn appeared to congregate in this favoured place. In the hollows and all about the roots of the pine stubs that bordered the woods at this spot ferns spread their luxuriant fronds. From little tufts still green as in the early Spring they ranged to giant stems four feet high and the dying under-leaves cast their woody fragrance in the air, adding to the indescribable diffusion of odours so impelling at this wonderful season. Creeping up the hill and crowning its crest, the pearly white everlasting held the flank of this wild garden, and the dying leaves of the wild strawberry, reminiscent of early Summer, gave a ruddy glow from their 


\section{THE BEECH WOODS}

lowly bed. The Spring, so rich in flowers and fresh with reviving life, seemed not to be compared to this riot of colour and perfume. Across the creek, beneath the beeches, standing along the sloping bank, the beech-drops thrived in tall brown ranks. This parasite plant draws its sustenance from the roots of the beech tree and develops two forms of flowers on its tall stems. At the top of its forking branches the tubular magenta flowers with purple stripes appear, and lower down the little flowers like buds sit close upon the upright stems and never open. Not far along the creek bank a few surviving plants of ginseng show their gaudy red berries. Its roots are shaped like the human body, and much medicinal value is attached to them by the Orientals.

Now followed the frosts which wilted all the remaining greenness and helped to shatter the leaves of the oak. No monarchs of the forest signalized the passing of the year with more glory than did the red oaks scattered throughout the Beech Woods. Their 


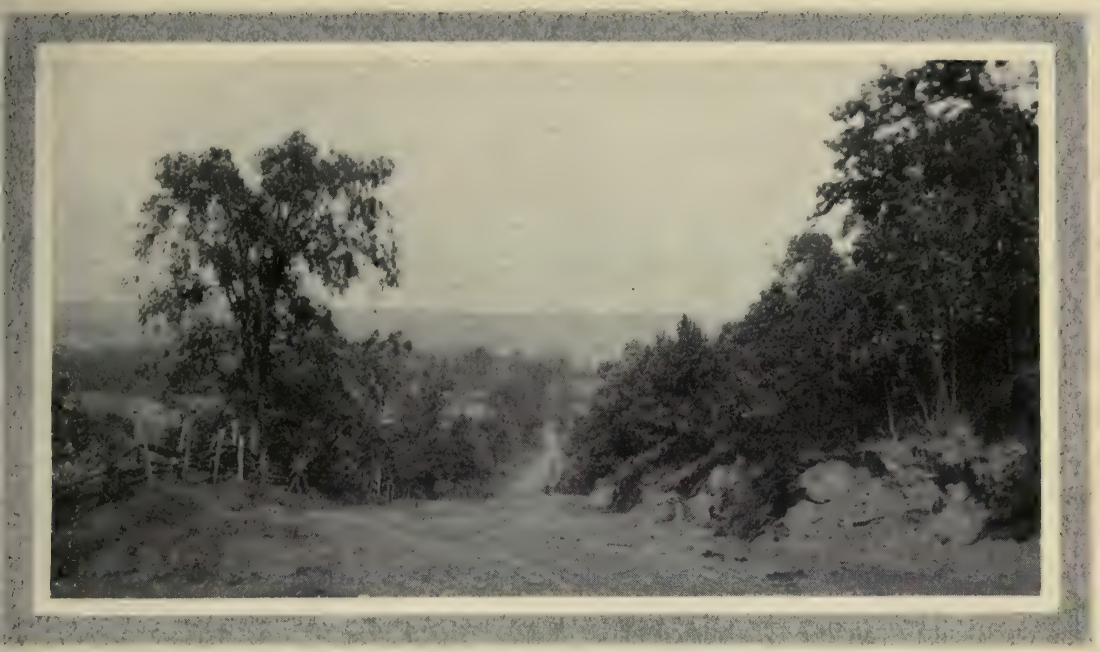

Down in the Valley of the Beeches. 



\section{AUTUMN}

broad, shiny leaves were the colour of dying fire, which glowed through the surrounding trees. But the frost and the wind brushed those from the trees, and the woods were bare except for the young beeches, whose pale russet leaves remain until the following Spring. The hollows were knee-deep with the fallen glory of the trees and proclaimed one's footsteps with noisy rustling. When the great winds of Autumn came the leaves·were sent scurrying before it in madly driving companies, while the great tops above swayed and roared in the throes of battle. Torrential rains came and transformed all the customary hollows to pools and set tiny streams a-singing in among the spreading roots.

Thus the season waned through sun and shower and frost toward November's end. Then came a day of languorous quiet with golden dust floating in the aromatic air and horizons veiled in blue haze. Indian Summer had come to cast her magic spell for a brief season upon the brown fields and leafless woods. These golden days of almost 


\section{THE BEECH WOODS}

Summer warmth were welcomed by all the little creatures of the woods, and birds appeared that might have been building new homes under the tropic sun. The hawks sailed over woods and fields and climbed up in the blue vault to sound their harsh cries and give a passing thought of Summer. Robins brightened the passing days with an old-time flash of red, but voiced no Summer song. The crows found much to interest them these delightful days, and many noisy councils were held in the different woods about. From morning till night their calls could be heard echoing along the forest ways, and any stray hawk or owl that chanced to visit their domain was subjected to the fiercest attacks and driven away. For countless generations the crows used to roost in the Niagara Gorge, flying over these woods late in the afternoon in long straggling flocks which stretched for miles from East to West. Since the Gorge of Niagara has been developed for industrial purposes the crows have deserted it and now roost in the pine woods hereabouts, but are 
very nervous and easily disturbed at night. Perhaps the many councils held in this quiet season are to decide the future roosting-place where they may rest in peace in safety. For a week those golden days continued in pleasing warmth, and still another came and went. But for the rising and the setting sun, time seemed to have no place nor season, because no change or development was apparent. All things seemed to rest, to dream and be at peace within the Beech Woods. The shadows that crept behind the tree trunks were always long and there seemed to be no noon, only morning and evening light treading softly down the gray archways. A meditative silence brooded over all, a silence eloquent with rest and contentment after a season of fulfillment. The choristers of yesterday were gone and only the little nests remained now filled with fallen leaves, marking the spot where their Summer work was done. All things within the woods were prepared for a season of rest and sleep, and the golden sun for a brief interval looked backward with a kindly smile. 

WINTER 



\section{WINTER}

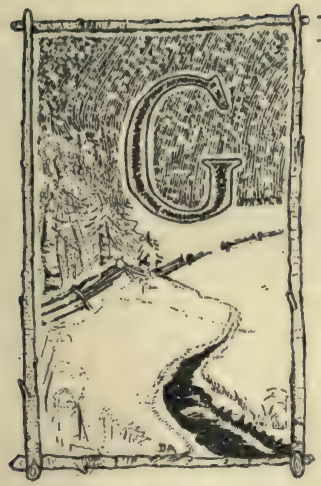

RAY December was passing.

When phantom frosts come each night and seal the surface of the pools with crystal bars, and edge the creek with spears, and coat the upper rails of the old fence with iwhite, the season of rest and sleep is not far off. Each day the dilatory sun slowly rises to cast its waning smile upon a world dressed in a symphony of brown. Each day it hastens to its filmy bed in the west as if reluctant to encroach, even for so short a time, upon these resting fields and woods.

One dull, frosty morning the rear guard of migrants came trumpeting down the gray pathway of the skies, proclaiming the near approach of Winter and setting strange echoes adrift upon the awakening world. Flying low, 


\section{THE BEECH WOODS}

in long, irregular lines, they came over the ridge to the north and went, honkhonking, on their way to the smiling South. These wild geese, reluctant to leave their northern breeding grounds, remained long after the great flight took place, but now, instinct warning them, they hurried to join their kindred before the Storm King should let loose his icy shafts.

A few days later the skies became dark, the west wind, which had been rushing through the gray woods, died down, and the family of partridges started energetically scratching beneath the shelter of the beeches on their knoll in search of food, making a noisy rustling among the dead leaves. Soon, however, the snow began to fall in large, loose flakes and the wind started up and swirled it about, beating it into every crevice and chink. Madly the flakes came racing and driving through the air, settling downward and then suddenly lifting and tossing upward, to dance and hesitate, then swing and circle gracefully downward to rest on the ground. In a few minutes the 84 

whole landscape was transformed with a mantle of white, and as the storm continued, even the trees of the woods became coated with the swan-soft vestment of Winter.

Night settled upon the woods and all sounds became muffled by the falling snow. When morning lifted her gray bars in the east and gradually fringed the snowy clouds with rose and mauve, a new world appeared, all white and clean and peaceful. If one would look upon the Winter as the season of sleep, when old Mother Nature tucks all her children 'neath the white, protective blanket of the snow, and then sends old Sol around betimes to see that all her children are asleep, we would have a much truer conception of the season of the snows.

Winter had laid her first ermine robe upon the woods with gentle hand. Each stump was crowned with white, as was each $\log$ and root, and all the limbs held a thick, soft layer, as yet undisturbed by even the gentlest breeze. The faded russet leaves of the young beeches, still clinging to the trees, were 


\section{THE BEECH WOODS}

loaded with tufts of fleecy whiteness, and all the interlacing branches appeared like one vast fairyland, whose enchanting aisles beckoned at every turn. In all the surrounding landscape there appeared no blemish, no unseemly bit to mar the spotless beauty of it. All undergrowth of roots and brush, each tiny tussock and mossy hollow was smoothed and levelled, making an undulating plain of marvellous white.

Winter had come, but all the wild folk of the Beech Woods were prepared. The raccoon had gone to his hollow in the old elm by the creek and would sleep away the long winter days in peace and comfort, for his fine coat was thick and warm and he was round with fat. The squirrels had laid up an abundance of nuts from the chestnut, hickory and beech trees and were comfortably sheltered in their homes in the trees. They would venture out at times on various quests and perhaps keep an eye on their hidden stores of food, but they would remain curled up with their bushy tails wrapped around them through the stormy days. The chip- 


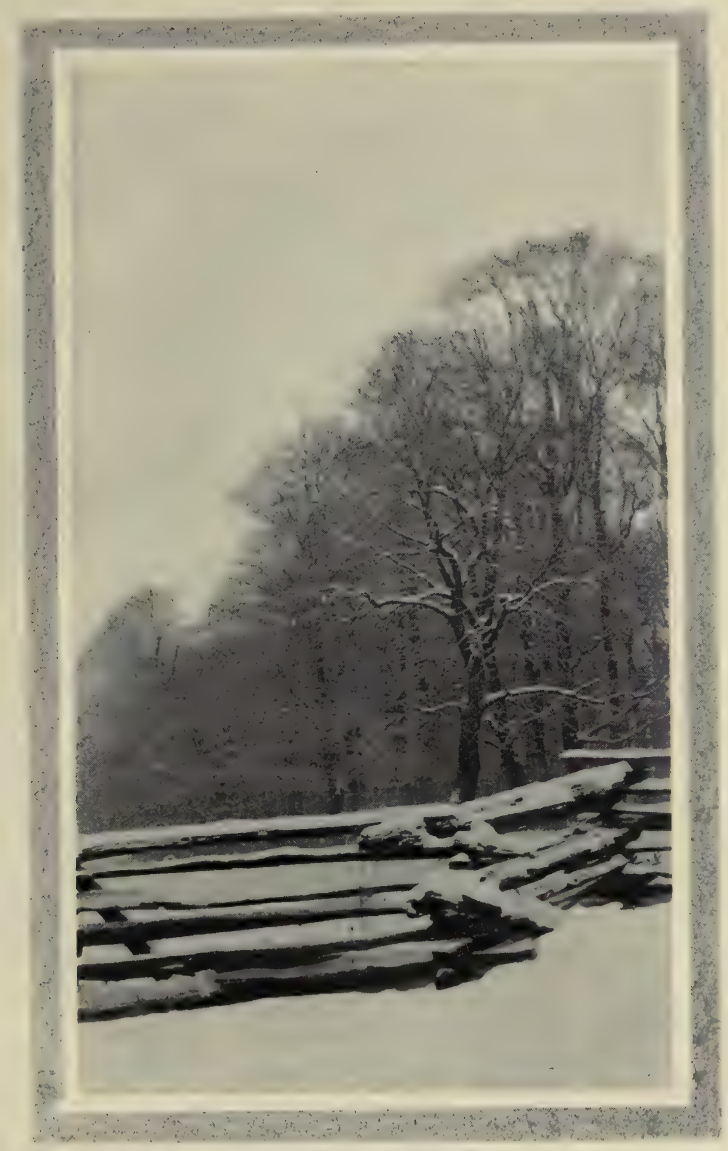

Winter's First White Blanket. 

munks were secure in their hollows underground or in the stumps, and seldom ventured out, as their food supplies were hidden in places easy of access, and they were very sleepy. Underneath the thick pile of pine brush the cottontails found shelter through the day and dozed in quiet sleep. At night they quietly came forth to nibble at the tender bark of certain shrubs and search out the protruding points of grass. This was a new world to all the younger ones who first saw the light of day in the Summer just passed. Now, full grown, they started forth upon strangely unfamiliar ways, so deeply covered with this soft, white, yielding blanket were their customary paths. This was a new experience added to their furtive lives, but, after the first few timid hops, they, like all wild creatures, accepted it as part of the great scheme of life.

The muskrats down in the bank by the old pond had made a dry, warm nest whose only entrance was through a hole underneath the water-line. The vagrant mink, who came searching 


\section{THE BEECH WOODS}

down the frozen water-courses, would find no easy entry into this home. Nor would his malignant little eyes find the home of the woodmice in the roots of the elm stub. The weasel, now wearing his ermine coat of white, with a black tip at the end of the tail, might also pass in his nervous, searching way, countless nests of field mice under the snow.

The partridges had selected the protection of the tamaracks for their roosting-place, and through the stormy nights they sat close beside the body of the trees, the thick, overhanging branches shielding them from the cold and storm. Although the carpet of snow covered their main food supply, they found plenty to eat, often visiting the birch trees growing in the thickets, for they liked the sweet buds. This morning they waited long before venturing out into the new world of Winter, but eventually; one by one, they came booming down the silent ways, touching a burdened branch or fanning the russet leaf-cups of the young beeches, and loosing a thousand fluffy 


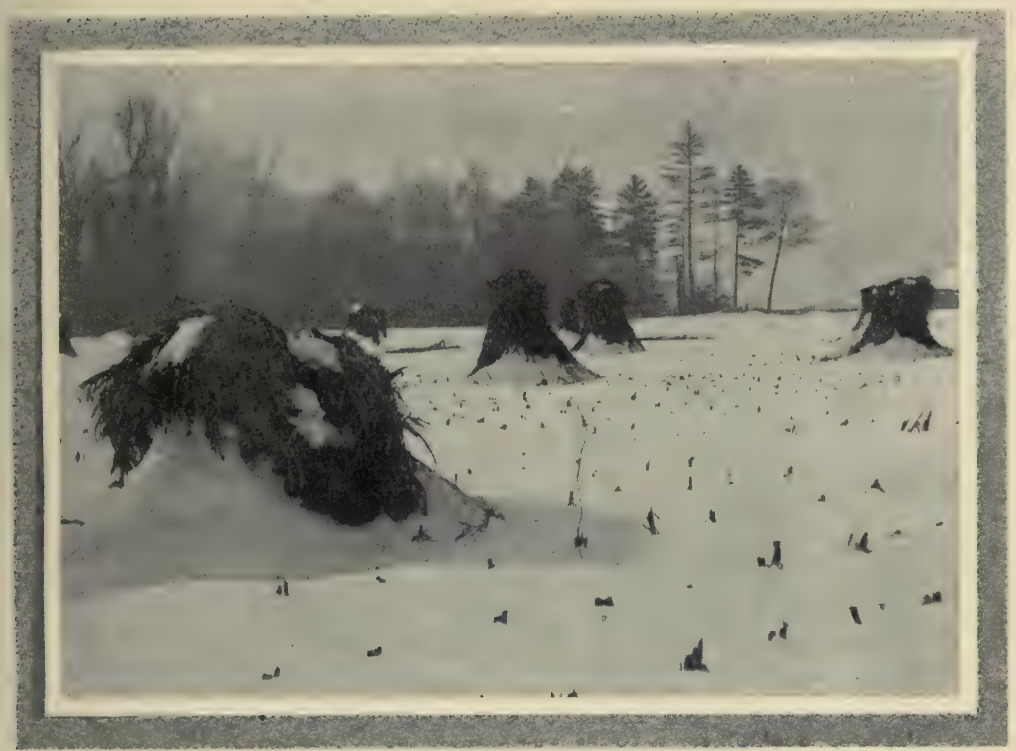

The Crows Knew Where There was an Abundance of Food. 

snow crystals which went floating downward to settle on the mother bed below.

About this time the blue jays awoke the woods with their discordant protests, but found little life in the snowbound forest to attract their attention. A pair of nuthatches came gliding down the rough bark of the maples, as if nothing had happened to disturb their rather lonely Winter vigil. They had taken the first snow as a matter of course and were busily on the hunt for a morning meal. A flock of confiding chickadees passed through, shaking the snow from the limbs as they examined each branch and twig, all the while conversing cheerfully with their musical notes, "Chick-a-dee-dee-dee."

The first storm found all the wild life of the Beech Woods prepared for all emergencies of cold and snow. Down beneath its protecting layer, and buried in the soft, black loam, the sleeping roots and latent buds of myriad flowers lay resting for the great revival in the Spring. The slim buds of the beech were sharp and long and shone like 


\section{THE BEECH WOODS}

burnished copper in the morning sunlight. The witch-hazel had only finished its second flowering when it had borne its dual blooms of yellow catkins and red button-like flowers on its spreading branches. Now its hardy buds, already looking abnormally large, were set and ready for the days when elemental forces would strive mightily above a dormant world of sleeping plants.

Thus Winter days passed by in changing moods of gray. Their variations ran from enticing warmth, when dripping trees and thawing snow made dark winding streamlets seek their way by lower levels, to the biting frosts of clear starlight nights, when these same streams were gradually sealed and silenced and the Frost King came to the Neighbour's house and painted fantastic designs upon the window panes. Through January cold and February snow the wind came, and in its breath the thickly smothering flakes that buried fences and creeks and obliterated all lowly objects in the woods and fields. Gray, mild days would come 


\section{WINTER}

sometimes with fields showing white against the dark horizon wall.

On such days the wood creatures showed increased activity, because they knew such days were usually followed by blustering storms. The squirrels descended the trees and dug away the snow in search of their hidden stores, littering the white carpet with leaves and not always finding the object of their quest. A few stray crows watched the activities of the squirrels with knowing side glances, but there was an abundance of food in the shocks of corn which had been left in the fields at the side of the woods, and they were content to remain inquisitive spectators.

One early morning, after a light fall, the Neighbour visited the woods. The heavy snows of early February were packed solid, and the thin film on the surface made an unbroken carpet on which all the moving wood folk left a record of their activities. In places, the squirrels had a maze of tracks between the trees, and crossing these were the dainty imprints of the cotton. 


\section{THE BEECH WOODS}

tail. Down by the flats of the creek the twin records of the mink were to be seen where he had wandered from tree to tree and from stump to stump. By the bank he had found an opening in a hollow log and had gone through it in the hope of capturing a rabbit, but only his tracks emerged from the farther end. Later, he came to the track of a rabbit and followed it for a short distance, but left it for some other pursuit. Beside the fences and in the open a tiny, trailing impression followed here and there, always from one object to another. These were the furtive imprints of the mice, in desperate haste seeking a needed meal far from their hidden retreats in the tunnels below the snow. They braved the dangers of the cold and all their natural enemies and courted swift death in the forms of the owl, fox, mink and weasel.

of all the tracks, the cottontail's is the most easily read. Each movement is registered as plainly as if he were before one. The Neighbour followed his trail and saw where he had stopped to nibble at a young tree. Evidently it 


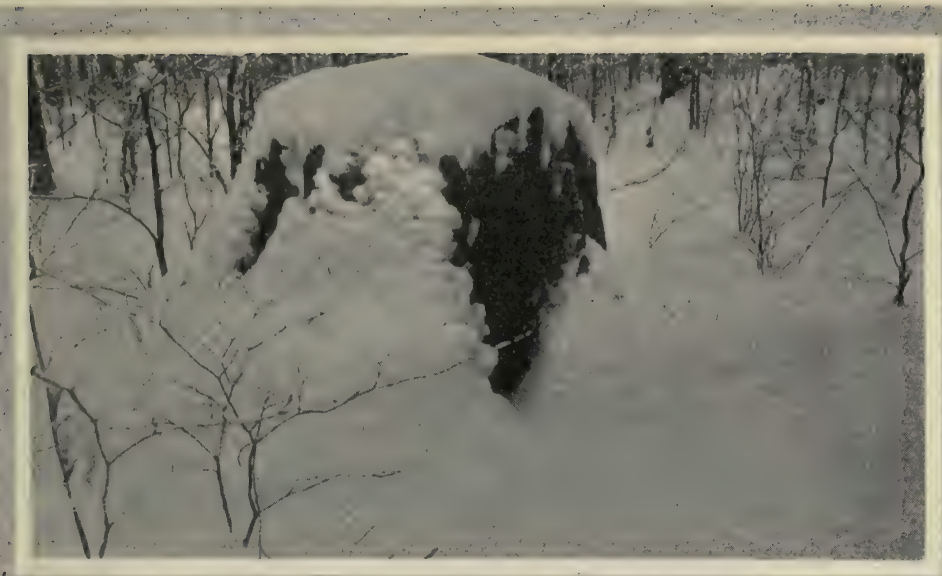

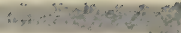

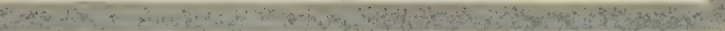

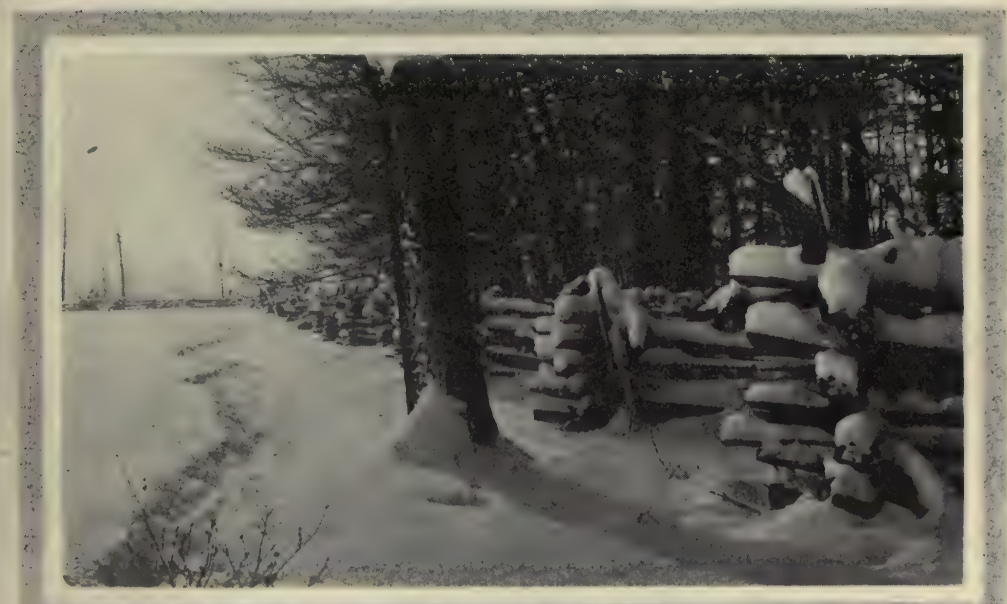

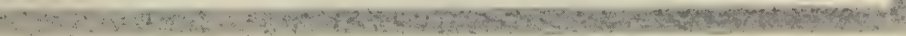

Each Stump was Crowned with White

The Winter Path. 

was not to his liking, for his imprints led off in easy hops for a few feet, where he stopped. Two little points in the snow and two heavy impressions of his hind feet showed where he had sat up to listen and look about, then he started off at a quickened pace, shown by the longer leaps. Presently he stopped again and sat up; this time, scenting danger, he was off in dodging leaps of eight feet, leaving only slight imprints of his dainty feet where they had flashed across the snow.

Out in the cornfield, about the prone shocks, the tracks of crows were to be seen, where they had swaggered about, and smaller prints of the jays showed where they too had found a welcome meal. A passing flock of snowflakes came sweeping over the field and settled on a hillside where some weed stalks stood out stiffly above the snow. While feeding on the seeds they twittered merrily, then, spying the Neighbour, rose suddenly and wheeled over the hill and away across the field out of sight.

Each day the sun became stronger and slowly burned ragged rifts in Win- 


\section{THE BEECH WOODS}

ter's fading blanket. Although the severest cold had passed, the Storm King occasionally raged through the fields and woods, reluctant to loose his icy grip, and piled the drifts behind the fences and the trees in fantastic banks. The whistling wind carried clouds of drifting snow which slid across the undulating fields, poured between the rails of the fence and came to rest in the lee of growing mounds.

At this time the bright morning sun greeted a world dressed in a robe adorned with dazzling brilliants and sparkling diamonds multitudinous in number. Rising higher, it flooded the woods and loosed myriads of scintillating snow crystals, which streamed downward through the interlacing branches of the trees, like so many transparent silver veils floating in air.

Now the bark of the beech tree becomes much lighter than at any other time of the year. There is a beauty about the clean, bright gray, a freshness caused by all the play of rain and frost upon its smooth surface. On the frosty nights of Winter's closing days, 


\section{WINTER}

the beautiful bark is adorned with efflorescent crystals. All through the early morning hours, down enchanted gray aisles and from the fan-shaped branches, these spangles of silver dust float in the air.

The mellow south wind arrived one day and started a thousand tiny streams, crowding and racing down the hillsides, and Winter hastily gathered up her tattered robes and fled. 

MORNING 



\section{MORNING}

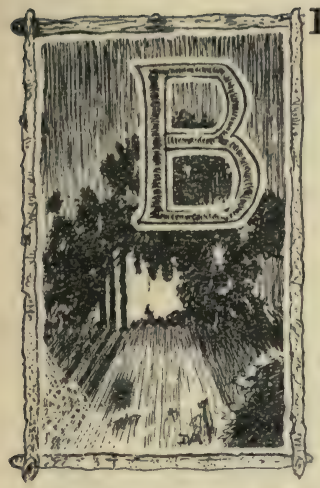

ENEATH the velvet gloom of sleeping woods there was no sound. Wrapped in the impenetrable canopy of night the flowers and birds lightly dozed through the slow morning hours, until the faintest trace of paler blue

blended upward in an arc above the low. woods on the horizon to the East.

A bird awoke and sleepily sang its song, while away in the pines a noisy crow proclaimed the awakening hours for his black kindred in hoarse caws that broke harshly on the Morning peace. Gradually the fading blue spread upward and ran around the horizon to North and South. In the centre of the fan of light the blue turned to ash-gray and the gray cloud became streaked with faint, opalescent light at the edges. 


\section{THE BEECH WOODS}

With the returning light as yet scarcely lifting the veil of darkness in the woods, the notes of hope and cheer became more frequent. For the feathered dwellers of these woods the night has its uncertainties, its sudden tragedies of storm or lurking death from winged or furred enemies. From thicket and from elevated perch more rejoicing songs broke upon the listening hours. This was the beginning of a new day and all things were refreshed and glad to be alive. In the growing light the gloom was dispelled and spirits rose, with all the various demands for action.

In the hollows of the creek a white mist hung, and dimly through it, like gray ghosts, tree trunks showed their many forms. Not a breath was stirring, and perfumes without number lay cradled in the air in unseen strata of variable depth. Here by a stump, where the sweet white violets grew, the air was heavy with their delicate perfume. The strong woody odour of the ferns floated in the hollows where they filled the spaces with luxuriant green. By the lane and on the strawberry-covered 
knoll, or in the hollow of the creek, the subtle scents, still undiffused, hung above their magic source. When passing through these invisible strata of the Morning air, one had a sense of walking in a fairy garden where rarest flowers grew in countless numbers, - each redolent of the ambrosial attar of the gods.

Now far on the southern horizon a single shaft of light showed in contrast to the sombre mist-clouds all about. Above the woods a great round cloud caught the rising sun's rays and glowed with light, reflecting it downward through the lattice of the trees, strangely illuminating the forest floor and awakening new choristers to song. The sun came peeping quickly, casting level rays across the fields, and faintly touching the eastern sides of the trees with ruddy warmth.

The pale mists came creeping down the hills and stole along the hollows in phantom companies. They lifted shadowy forms that rose and fell and slowly waved their trailing veils. They 
followed down the hollows in grotesque shapes, enveloping the trees in their ghostlike arms, then spreading, came creeping flatly along the ground to rise and pour over the low fences and gradually vanish in the sunlight.

Each blade of grass and leaf held its crystal of dew which sparkled from its green setting like a perfect peridot. The little spider webs, cunningly set in the grass, held a film of moisture which turned the transparent nets into silver veils, incidentally disclosing to all passing insects the secret web of death.

An early, chipping sparrow emerged from a bush by the fence, nervously twitching her tail, and wiped her bill on a dead twig. A hurrying bee sped through the Morning mist, its droning flight sounding full of promise as it disappeared. A red-headed woodpecker pounded a tattoo on a hollowed tree and sent loud echoes flying back and forth, disturbing the quiet.

Now a voice of alarm sounded in the Beech Woods this Summer Morning. It spread abroad from East to West 


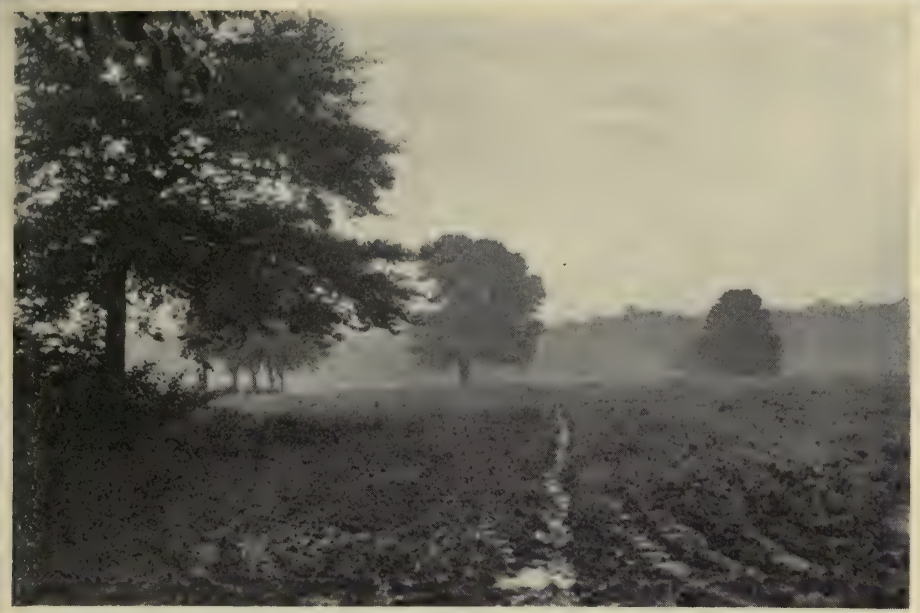

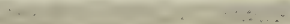

The Morning Mists Came

Creeping Down the Hollows. 

and from North to South, and filled each feathered breast with a furtive restlessness. Watchful eyes were alert to all movements and all ears strained to catch the slightest sound. The crows had discovered an enemy and, with a clamouring uproar, were congregating from all directions.

In the top of a sugar maple it sat, opening its large eyes now and then in dazed fashion and stupidly twisting its head about in jerks. The crows moved all about it, keeping a respectful distance, however, but setting up a steady, deafening din of harsh cawing. This short-eared owl, remaining out on a protracted search for mice or larger game, had been discovered by the crows and followed relentlessly. Now it essayed escape in dodging, but its usual steady, silent ways were changed to tentative flight from one thick tree to another, while the crows dived and menaced it from all sides, breaking out afresh each time in their bedlam of noise.

In all the owl's short and stormy pas103 


\section{THE BEECH WOODS}

sages it had been working toward the pine groves to the North, and by some quick move or by a long flight it lost its pursuers. Gradually the noise died down and peace was restored. The more wary of the songsters who remained hidden came forth to do their Morning carol. The vireos sat in the upper branches and sang unceasingly. From all the woods and fields the great chorus swelled and grew in volume until the nearest songsters sang their solos accompanied by the fainter blinding notes of the multitude. What a revelation this would be to the city dweller, who so rarely sees the sun come smiling over the horizon! What a feast for the noise-ridden ears of the toiler to walk in the awakening fields and hear this wonderful chorus so eagerly flooding the world with joy!

In this early Morning light that wakes the sleeping hollows and puts to flight the nocturnal life of the woods, there is a fascinating power. It comes so cheerfully tripping down the long vistas and peeping through the trac- 


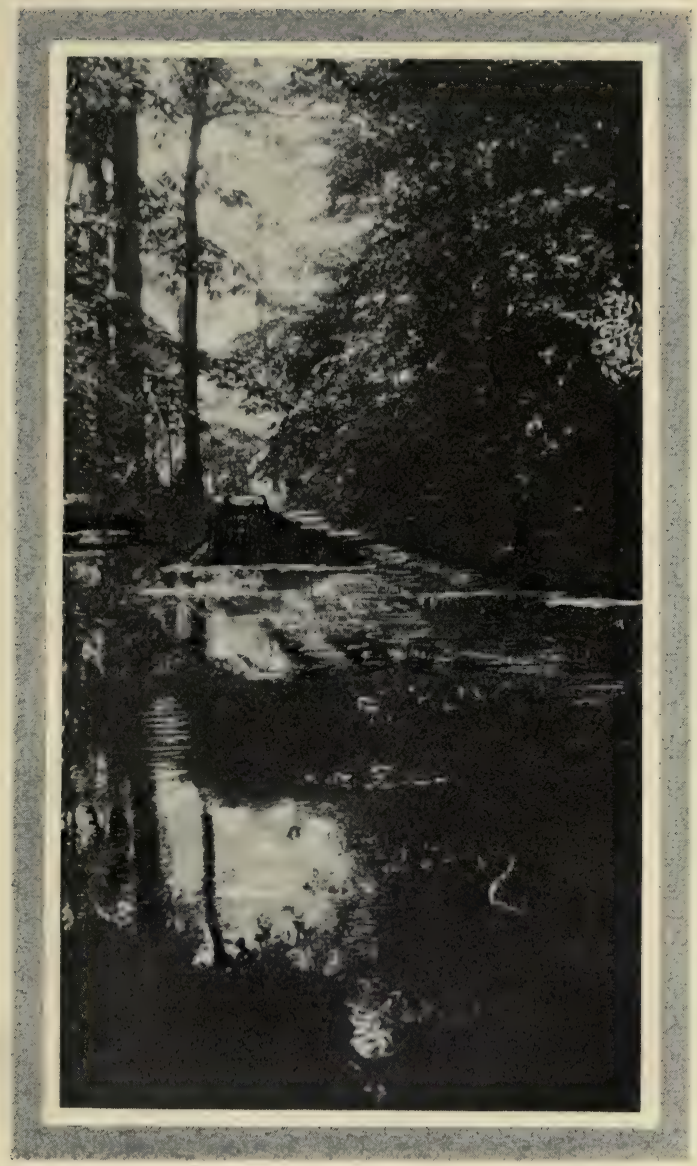

The' Morning Light. 



\section{MORNING}

eries, following round the graceful boles of the gray trees to linger on the flowers and the bare mosaic of the forest bed. Gradually it loses its Morning gold, the shadows become shorter, and the feathered tribes of the wood take up the business of the day. 

NIGHT 



\section{NIGHT}

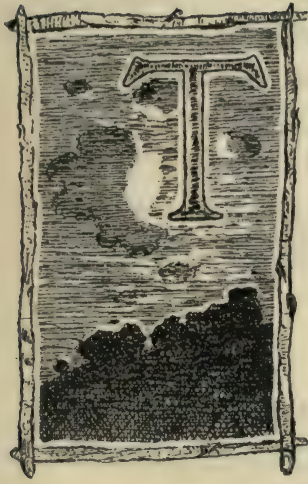

HE low sloping sun that, through the day, played hide-and-seek with large, loose clouds, now settled in a sea of flaming colour. Spreading from the rose and amber of the lower bars the light went blazing outward in little waves, while, resting motionless, high above the parent cloud a tiny group, like a flock of birds, were swept with radiant gold. Soon the distant crests of brilliant colour began to dim to shades of old rose and gray as twilight came to close the shutters of the day and set the vesper star a-twinkle.

While the sun still hung above the western rim, the homely sounds of the countryside died down. Except for the song sparrow's note, the fields were silent, but in the Beech Woods the music of two inspired songsters lent 


\section{THE BEECH WOODS}

enchantment to the magic hours of fading light.

At regular intervals a weird and fascinating song came echoing from the edge of the woods. Beginning with a high note, it went rippling down the scale in rounds, clearly resembling the wind music of the reed. The song of the veery is like no other bird's and has a wild charm about it which stirs the pulse and excites the curiosity of the uninitiated. Often to the boy it draws like a magnet, but, unlike a magnet, the nearer he gets to it the harder it is to find, for it is rather shy and ceases its wonderful song when approached. One of these youthful admirers, in the days before he learned the difference between the major and the minor, set at nanght the eulogies of the naturalists and thus characteristically described its song: "It sounds like a marble rolling down a gun barrel."

Here by an open brake among the trees the veery sat, dressed in his reddish-brown suit, and under parts a dull white with faint markings on his breast. Each time he ran his cadence 


\section{NIGHT}

he began with a low note which carried only a short distance, but the volume of his song could be heard far across the fading fields.

Back on the beech knoll the woodthrush let loose a marvellous flow of flute-like melody in little bursts of song. His is the richer, but lacks the wild attractiveness of the veery. $\mathrm{He}$ has a great range and a variety of at least six songs, with many notes resembling the flute. A striking bird is he, dressed in reddish-brown from head to. tail, and white breast heavily dotted with black. He is more sociable than the veery, and will sit and pour forth his wonderful music within easy sight.

Thus he continued through the hour of sunset till twilight came. Thus this time of tensest stress, when life runs high in all the winged creatures, was intensified by these seductive notes. A violet gauze draped itself about the fences and crept from bush to bush and from tree to tree. Vague, fantastic shapes seemed to flit about, always moving with the deeper shadows and finally dissolving in their midst. With 


\section{THE BEECH WOODS}

the deepening chrome came the great hush of evening, so eloquent with rest and mystery. For in the gloom of Night the forest creatures, full of pentup energy, moved furtively about within it, and yet were a part of this calm, waiting silence.

One June evening found the Neighbour walking up the path in the woods just as the sun was sending its last gleams through the lace-work of foliage. An odd song was to be heard near the ovenbird's nest, and the silver rounds of the veery, with its elusive beauty, came echoing through the gray archways of the listening woods. After the shades of dusk advanced from the borders of the creek and enveloped the trees standing isolated in the flats, the fireflies began to flash and gleam their eerie, phosphorescent lights in wavering flight. As the darkness settled, the luminous tiny flashes increased until the sombre veil that hung over the open marsh was animated with hundreds of these glowing lights.

Up in the high woods another wonder of the insect world was taking 


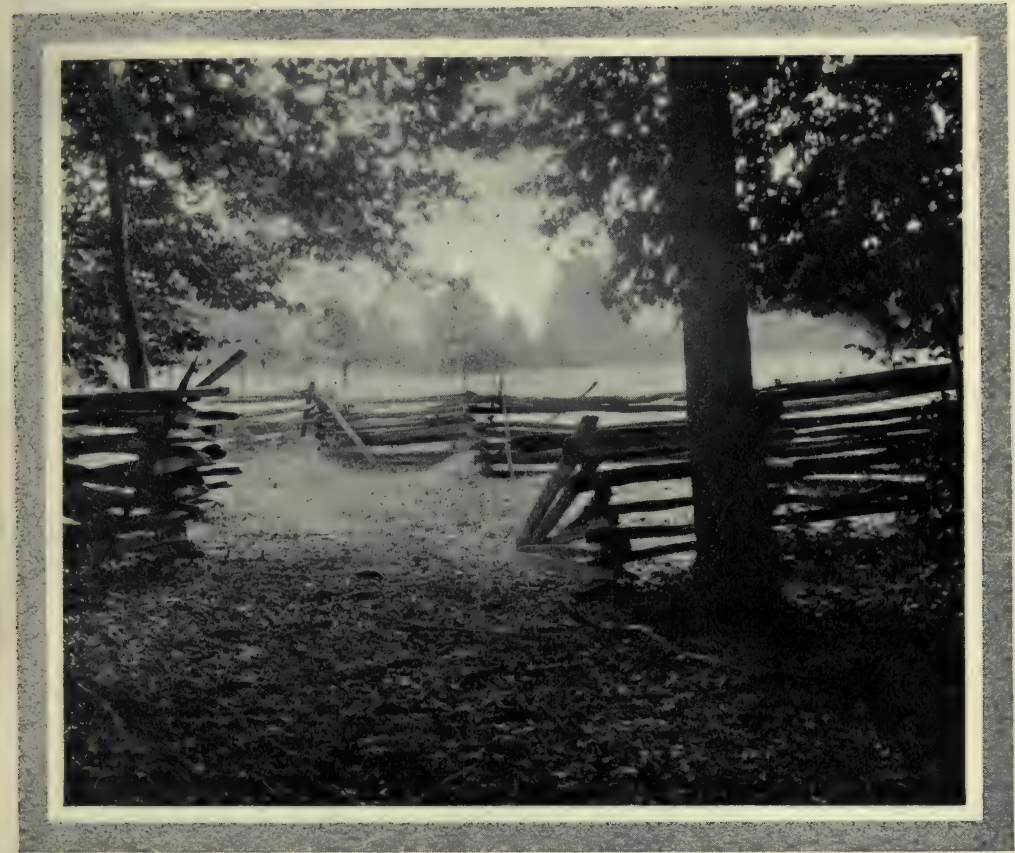

The Magic Silence of the Evening Settled Over Fields and Woods. 



\section{NIGHT}

place, and, while not so spectacular as the flight of the fireflies, was watched, or rather heard, by the Neighbour with passing interest. After dusk had settled and the woods were. wrapped in silence, a brief buzzing sounded among the leaves on the ground near by. Presently another buzz came from a little distance, and the sound went on increasing until the droning of the "June bugs" in flight was mingling in general concert with those attempting to rise from their hiding-places among the leaves. These large brown beetles had passed the daylight hours in safety, and now came out from secret places to flutter and rise.

As the insects rose in increasing numbers, the volume of sound grew until a deep hum pervaded the woods. It did not stop here, but still grew to a vibrant bass, like the drone of numberless bass viols. Countless numbers of these insects, circling about the tree-tops, touching the foliage in their erratic flight before they settled among the leaves, made this almost unbelievable sound. Gradually the vol- 


\section{THE BEECH WOODS}

ume decreased, the great hum died down, and presently the wonderful silence of the woods was again unbroken, except for the occasional rustle of an insect falling through the leaves.

The Neighbour wandered on to the home of the screech-owl, at a turn in the path where, in a beech stub, the pair of night watchers had their nest. A plaintive note came from near the home tree, and presently the soft whirr of passing wings and the vicious snap of a powerful beak uncomfortably near his ear told the Neighbour the little owl was not to be trifled with in his own domain. All that was to be seen or heard in the darkness was a dull flash, a whirr and a sharp snap, as the owl repeatedly dived at the intruder. To say the least, the suddenness and uncertainty of attack would be most disconcerting to any night marauder seeking its young or even wandering near the old beech stub.

Out of the ferns at the edge of the path there came a sudden flash of white and the soft patter of many padded feet went down a trail to the left. It was a 


\section{NIGHT}

mother rabbit with her family, waiting hopefully to be passed but, fearing discovery when too late, she led her gamboling young a fast pace for a little distance to the protecting thicket of young maples.

Here in the open upper woods the bats circled about in their erratic flight, never seeming to rest or to vary that silent winnowing movement of the wings. In a hollow beech, not far from the path, a mother skunk was building a nest and came through the leaves in her awkward way, making a loud, rustling which broke the stillness. She came to the edge of the path and cut the long grass growing there, bending it over with her forepaws and slashing it off with a dull, ripping noise. When she had a sufficient quantity she started: backing toward the nest, rolling the grass after her.

Thus through the gloom of Summer nights these little forest dwellers lived their furtive lives. A thousand vagrant detours marked their tiny trails that led through the tangled copse or round the rugged roots of some great beech 115 
or maple. What wild promptings stirred these shadowy forms to ever move with crafty vigilance upon their endless journeys? No tentative pursuit was begun without the searching of the forest ways with covert eyes and listening ears, or upturned, delicate nose to sense the presence of an enemy. Sometimes the playful young cottontails would scamper out into the bright moonlight that lay in irregular patches across their paths, or by the open fields at the edge of the wood. But when the fresh scent of lurking mink or weasel crossed their trail, they used their one great natural protection and sped away on nimble feet in dodging leaps.

Sometimes when the Night had dreamed in moonlight past the midnight hours, a sleepy bird would awaken strange echoes by pouring forth its full song. How full of hope these little feathered folk must be to overflow with joy in the dark hours; or, perhaps, they dream of the bright sunshine and the activities of the day and live them over again, like the Neighbour's dog who followed the chase again at night while 


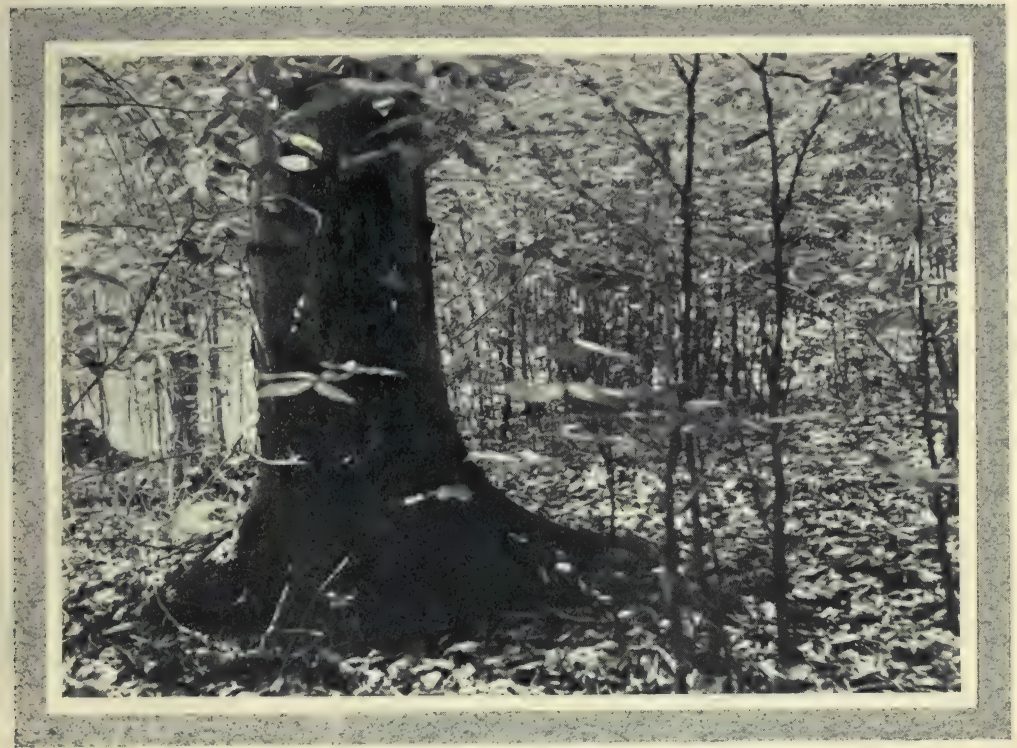

The Moonlight Came Filtering Through the Trees. 

curled up behind the stove, and barked and whined and thumped the floor with his tail, all in a dream.

When darkness settles, Night holds a tragic silence in the woods-a velvety softness, in which the merest sound has a depth of meaning and a breadth of mystery there in the gloom. One winter's night brought a great surprise to all the country folk living about the neighbourhood and caused strange things to happen in the Beech Woods. The light failed early this evening and Night settled down as usual. Early in the morning hours strange noises were heard that aroused vague fears. Muffled crashing sounds came at intervals and grew in number, booming out across the snow-covered fields. It was discovered by those who were disturbed by the strange sounds that a heavy blanket of wet snow had silently fallen, and as it settled on each limb and branch the weight of it brought them broken to the ground. The woods were wrecked of all the weaker limbs and whole trees were prostrated beneath the weight of this silent storm. 


\section{THE BEECH WOODS}

Each season had its changing moods and its variable nights. The hope of Spring or the bloom of Summer cannot approach the Autumn Night of rare aromas and enchanting moonlight. The woods were wrapped in calm repose, yet seemed to pulsate in the soft flood that bathed all objects and hung above the far horizon like a bridal veil. From the new-sown wheat fields the scent of burning pine came floating through the air, and the glow of burning stumps marked the border of the new-ground. On these nights the quavering voice of the little owl echoed across the fields and was answered in the neighbouring woods by another plaintive call. All through the hours of shimmering light these soft voices answered back and forth, adding a magic touch to the romantic Night.

Later in the season of falling leaves the rains came and flooded the creek and the raccoon came down to search for frogs in the pools and shallows. In years gone by these furred creatures were plentiful in the Beech Woods, and in those days of the mu: le-loader the 
Neighbour used to follow their haunts with his dog.

On these nocturnal rambles he learned the habits of the wood mice, with their large eyes and long, delicate earsbeautiful little creatures they were. He studied the stars that winked through the lattice of the trees or watched for the strange lights that used to rise and hang over a low wood to the south. He learned the meaning of each Night sound that came to him in these silent watches. The baying of a pair of hounds away up the hill came faint and far to tell of the wise little cottontail eluding its pursuers. The pungent odours of the forest were known in time, but best of all he grew to understand the wind that came when trees were bare and sighed or moaned or whispered gently by his feet. Under the great arches were heard the harmonies of the ancient wood sighing for its vanished tribes, moaning for its lost people.

From the great organ music that rose and fell in deep symphonies the tone died down and became soft and gentle 


\section{THE BEECH WOODS}

like a distant harp. It was the voice of the past coming down the vista of the years and bearing in its breath all the mystery of the woods and all the sadness too. 



\section{PLEASE DO NOT REMOVE CARDS OR SLIPS FROM THIS POCKET}

\section{UNIVERSITY OF TORONTO LIBRARY}


